\title{
SIN ALTERNATIVA A LA PRISIÓN: EL PERIODO DE SEGURIDAD Y LA FINALIDAD RESOCIALIZADORA DE LA PENA PRIVATIVA DE LIBERTAD
}

\author{
Eva Dominguez IzQuiERdo \\ Universidad de Jaén \\ E-mail: evadomin@ujaen.es
}

\begin{abstract}
RESUMEN: La declaración constitucional contenida en el art. 25.2 aun cuando no se configure como un derecho subjetivo susceptible de amparo, interpretada de forma menos limitada a la exclusiva proyección a la ejecución penitenciaria, sirve para rechazar las penas de prisión de larga duración y para discutir la pertinencia del denominado "periodo de seguridad" que, introducido por LO 7/2003, obliga a cumplir, en ciertos casos de forma imperativa, una parte de la pena de prisión no susceptible de remisión. Este periodo blindado en el que parte de la pena debe cumplirse irremediablemente en el Centro penitenciario sin que pueda obtenerse el tercer grado de tratamiento antes de cumplir la mitad de la pena, supone un elemento extraño al principio de flexibilidad inherente al sistema de individualización científica vigente en nuestra LOGP, al fundarse exclusivamente en el dato de la gravedad de la pena y el cumplimiento de cierto periodo de tiempo, lo que nos retrotrae el sistema progresivo que creíamos superado y nos acerca a fines de prevención general.

La atenuación del rigor que supuso la reforma de 2010 configurando el instituto como potestativo y la posibilidad de vuelta al régimen ordinario de cumplimiento, no logra evitar la disfuncionalidad que supone que sea el Juez sentenciador quien decida, al margen del tratamiento penitenciario, la adecuación de una figura que afecta a la ejecución, sin precisarse con qué criterio, ni soslayar las dificultades que presenta el proceso de revocación del mismo, en el que también interviene activamente la víctima.
\end{abstract}

Palabras clave: reinserción, periodo de seguridad, pena privativa de libertad, individualización científica.

ABSTRACT: The constitutional declaration contained in art. 25.2, even when not configured as a subjective right subject to protection before the Constitutional Court, if interpreted in a less limited manner than the exclusive projection of penitentiary execution, serves to reject long-term custodial sentences and to discuss the relevance of the so-called "security period" which, introduced by the Organic Law 7/2003, obliges to fulfill, in certain cases in an imperative way, a part of the custodial sentence not susceptible to remission. This armored period in which part of the sentence must be 
irretrievably served in the penitentiary facility without being able to obtain the third degree of treatment positions itself as a strange element to the principle of flexibility inherent in the system of scientific individualization in use in our LOGP as it is based exclusively on the degree of severity of the sentence and the fulfillment of a certain period of time, which takes us back from the progressive system that was believed to have been overcome and brings us closer to the purposes of general prevention.

The attenuation of the rigor that the 2010 reform entailed, configuring the institute as optional and the possibility of returning to the ordinary regime, does not manage to avoid the dysfunctionality that is generated when the sentencing judge decides, apart from prison treatment, the adequacy of a figure that affects the execution, without specifying the criteria used to decide, nor avoiding the difficulties that the revocation process presents, in which the victim also actively intervenes.

Keywords: reintegration, security period, custodial sentence, scientific individualization.

SUMARIO I. Premisa: la Resocialización Como fin de la pena y la inCREDUlidad del legislador. II.

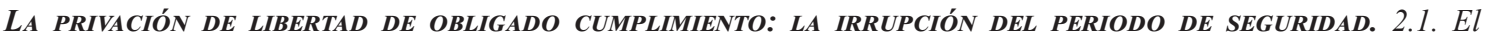
sentido político criminal de la figura. 2.2. Modalidad genérica, agravada y excepcional del periodo de seguridad. 2.2.1. Modalidad genérica. 2.2.2. Penas superiores a cinco años. 2.2.3. El periodo de seguridad cuando recae una nueva condena. 2.2.4. Regreso al Régimen general de cumplimiento: la revocación del periodo de seguridad. 2.3. Régimen excepcional. III. REQUiSITOS ADICIONALES PARA LA OBTENCIÓN DEL TERCER GRADO. 3.1. Satisfacción de la Responsabilidad civil. 3.2. Abandono de los fines y medios terroristas. IV. EL PERIODO DE SEGURIDAD EN LA PRISIÓN PERMANENTE REVISABLE. V. BIBLIOGRAFÍ.

\section{PREMISA: LA RESOCIALIZACIÓN COMO FIN DE LA PENA Y LA INCREDULIDAD DEL LEGISLADOR}

Cuando se alude al art. 25.2 CE en relación con la orientación hacia la reeducación y reinserción social ${ }^{1}$ que debe guiar a las penas privativas de libertad ${ }^{2}$-aunque también a las

1 El tenor literal del precepto es mucho más amplio comprendiendo otros aspectos relativos a la ejecución de la pena de prisión: "Las penas privativas de libertad y las medidas de seguridad estarán orientadas hacia la reeducación y la reinserción social y no podrán consistir en trabajos forzados. El condenado a pena de prisión que estuviere cumpliendo la misma gozará de los derechos fundamentales de este capítulo, a excepción de los que se vean expresamente limitados por el contenido del fallo condenatorio, el sentido de la pena y la Ley Penitenciaria. En todo caso, tendrá derecho a un trabajo remunerado y a los beneficios correspondientes de la Seguridad Social, así como el acceso a la cultura y al desarrollo integral de su personalidad".

2 Las penas privativas de libertad son, a tenor de la Reforma operada por LO 1/2015 en el CP y según el art. 35, la prisión permanente revisable, la prisión, la localización permanente y la responsabilidad personal subsidiaria por impago de multa. Esta última puede, según lo establecido en el art. $53 \mathrm{CP}$, cumplirse mediante localización 
medidas de seguridad, sin que se mencione la índole de estas que pueden ser privativas o no de libertad- se está haciendo referencia implícita a los fines de prevención especial positiva $^{3}$ que se le atribuye, aunque no como fin exclusivo, a las sanciones penales ${ }^{4}$. En este sentido, puede advertirse que nada dice el Texto constitucional acerca de otros fundamentos o fines de la pena (prevención especial negativa y prevención general). Por ello, no puede confundirse esta declaración orientada esencialmente al ámbito de ejecución penitenciaria ${ }^{5}$ donde rige el sistema de individualización científica, con el fundamento mismo de las sanciones penales, sea cual sea su naturaleza ${ }^{6}$.

En suma, la ausencia de mención en la redacción del citado art. 25.2 CE a otros objetivos de la pena de prisión podría suscitar dudas acerca de si la reinserción es la única finalidad constitucionalmente avalada, si es la función preponderante o si es un objetivo del que puede prescindirse cuando primen otros fines, por ejemplo, de prevención general, básicamente en su versión intimidatoria. Pese a las tensiones que puedan plantearse en relación a la prevalencia de otra de las funciones de la pena ${ }^{7}$, lo cierto es que se debe destacar la no exclusividad de la resocialización como fin del Derecho punitivo y sus instrumentos. De lo contrario, podría concluirse que la pena deviene innecesaria cuando el sujeto no requiere ese trabajo de resocialización por estar perfectamente integrado o porque no es posible llegar al objetivo previsto (bien por ser la pena corta, por tener el penado una edad muy avanzada o por ser un delincuente por convicción), lo que no sería admisible atendiendo no solo a la función de protección de bienes jurídicos que el Derecho penal persigue - mirando hacia el futuro- mediante la imposición de la pena, sino, al hilo de lo anterior, por cuestiones de prevención general.

permanente (si fuera un delito leve) o trabajos en beneficio de la comunidad a razón de un día de trabajo por cada día de privación de libertad.

3 No es usual encontrar declaraciones de esta índole en Textos constitucionales. Como excepción, cabe mencionar, la Carta de Italia (art. 27.3) donde se señala que las penas, en general, no pueden ser contrarias a la humanidad y "deberán encaminarse a la reeducación del condenado" y la de Méjico (art. 18.2) cuando refiere que el sistema penal debe organizarse "sobre la base del trabajo, la capacitación para el mismo y la y la educación como medios para la readaptación social del delincuente".

4 Art. $1.1^{\circ}$ LOGP recoge que las Instituciones penitenciarias "tienen como fin primordial la reeducación y la reinserción social de los sentenciados a penas y medidas de seguridad, así como la retención y custodia de detenidos, presos y penados". Fórmula repetida en el art. 2 del Reglamento Penitenciario (RP), donde se asevera que es el "fin primordial". Del mismo modo, el art. 59 LOGP establece: 1. "El tratamiento penitenciario consiste en el conjunto de actividades directamente dirigidas a la consecución de la reeducación y reinserción social de los penados.

5 Como evolución del sistema progresivo en la ejecución de las penas que impulsara en España MONTESINOS en los albores del S. XX conjugando los avances en la resocialización con la buena conducta y el trabajo, determinando un progreso en grados desde el más severo, pasando por la semilibertad y terminando con la libertad condicional, en nuestro Ordenamiento rige el denominado "sistema de individualización científica" impulsado por la CE de 1978 y la promulgación de la LO 1/1979 General Penitenciaria, que lo consagra. Vid. art. 1 que lo conecta con el art. 25.2 CE y judicializa al crear la figura del Juez de Vigilancia Penitenciaria (JVP).

6 En este sentido, la STC 55/1996, de 28 de marzo (La Ley4318/1996), en un supuesto en el que se alegaba la desproporcionalidad de la sanción penal prevista para la insumisión al servicio militar, distingue entre un fin esencial y directo de protección al que responde la norma, de otros fines legítimos que puede perseguir la pena (funciones o fines inmediatos entendidos como prevención general y especial).

7 El problema del actual Derecho penal se encuentra en el conflicto existente entre prevención especial y prevención general, que, en definitiva, traduce el eterno conflicto entre individuo y sociedad. Respetar los derechos del individuo en relación a su resocialización, garantizando, al mismo tiempo, los derechos de una sociedad que tiene derecho a proteger sus intereses más importantes recurriendo a la pena cuando sea necesario lleva a concluir que, una vez reconocido que en la sociedad actual los fines de la pena han de estar necesariamente dirigidos a la prevención, la tensión dialéctica no es fácil de resolver sobre todo si se pretende buscar la coherencia de un sistema y no hacer política populista. 
En efecto, con múltiples matices, hay que considerar que la pena desempeña también -básicamente en el momento de la conminación legal y en el de su imposición judicial- una función de prevención general, siempre atendiendo a unos principios limitadores que impedirían legitimar el recurso a la pena atendiendo exclusivamente a su eficacia intimidatoria porque ello podría conllevar penas desproporcionadas. Sin embargo, la prevención especial positiva no siempre es necesaria ni siempre es posible por lo que su sola mención tampoco justifica por sí el recurso a la pena, aunque, sin duda, ésta deba propender a la resocialización o impedir, al menos, la desocialización del condenado. Ello no implica, en sentido contrario, que la pena deba imponerse siempre y en todo caso por razones de justicia, lo que nos acercaría a posiciones retribucionistas y al margen de todo tipo de objetivo resocializador, pues en todo el proceso deben estar siempre presentes los principios de necesidad de pena y proporcionalidad.

Las categorías de prevención general y especial atienden a las diversas influencias que la pena en su discurrir (desde el momento incriminatorio o de conminación legal hasta la ejecución final, pasando por el momento de concreción y el aplicativo) proyectan sobre el comportamiento de las personas, utilizando instrumentos como la intimidación, la confianza y el refuerzo del Derecho (prevención general negativa y positiva), reeducación - que el legislador constituyente ha materializado en el art. 25.2 CE- e, incluso, inocuización ${ }^{8}$ aspecto que está presente no sólo en las penas largas privativas de libertad sino también en la mayoría de las penas inhabilitantes. El Derecho penal se legitima así por su función preventiva (general y especial) desarrollada siempre en el marco de los principios limitadores y de carácter garantista propios de un Estado de derecho: legalidad, culpabilidad y proporcionalidad ${ }^{9}$, esencialmente.

En un inicio, los términos reeducación y reinserción social tuvieron un contenido de soporte clínico centrado en la personalidad del sujeto que, sometido a un tratamiento voluntario adecuado, terminaría por neutralizar la tendencia delictiva, incluso cayendo en una retórica moralista inadmisible en un Estado de derecho que reconoce el libre desarrollo de la personalidad ${ }^{10}$. En un momento posterior, trasladado el concepto al marco penitenciario a fin de mejorar las condiciones de cumplimiento y facilitar el tránsito a la libertad potenciando los contactos con el exterior, el concepto no se refiere tanto a la educación para "vivir en libertad", sino en el intento de que la estancia en un centro penitenciario no disminuya o anule las perspectivas resocializadoras. En este sentido, puede afirmarse que la resocialización se conforma, para verse cumplida, con la no desocialización.

En cuanto al alcance del término, algunas voces en la doctrina se mostraron en su momento partidarias de restringir el principio constitucional exclusivamente a la ejecu-

8 ATC 780/ 1986 de 15 de octubre (La Ley 4875/1986) ya advertía que la reeducación y la reinserción social no es la única finalidad legítima de las penas privativas de libertad. La STC 150/1991 de 4 de julio (La Ley 1759TC-/1991) indica, al hilo de un recurso sobre la agravante de reincidencia, que tampoco se opone el art. 25.2 CE a otros fines de la como la prevención general. En el mismo sentido STC 234/1997 de 18 de diciembre (La Ley 385/1998) respecto al delito de negativa a la realización de la prueba de alcoholemia recogido en el art. $380 \mathrm{CP}$ en aquel momento.

9 De este último deriva el principio de humanidad que proviene, a su vez, de la dignidad de la persona.

10 Vid., en esta línea, el propio concepto que aporta el art. 59.2 LOGP como "la intención de vivir respetando la ley penal, así como la de subvenir a sus necesidades". Críticamente respecto a esta visión, ya en el origen de la Ley citada y, ampliamente, MUÑOZ CONDE, F., "La resocialización del delincuente, análisis y crítica de un mito". CPC, 1979 y GARCÍA PABLOS DE MOLINA, A., "La supuesta función resocializadora del derecho penal: utopía, mito y eufemismo". $A D P C P, 1979$. 
ción penitenciaria ${ }^{11}$. No obstante, superadas estas posiciones, las posturas dejaron de ser tan estrictas, no limitando el alcance del principio resocializador a la ejecución de la pena de prisión y, ni siquiera en exclusiva, a las penas privativas de libertad ${ }^{12}$. De este modo, todas las sanciones que el CP ha previsto como consecuencia jurídica anudada a la comisión de un ilícito penal, deben propender -no exclusivamente, sin duda- al fin resocializador. Y se trata de un cometido que no solo ha de guiar la forma de cumplimiento sino que va más allá y se convierte en un mandato dirigido al legislador tanto en su previsión legal como también en el momento de la correspondiente aplicación judicial. En definitiva, debe impregnar todo el proceso sancionador desde la tipificación hasta la fase final de la ejecución ${ }^{13}$ dentro y fuera del Centro penitenciario.

Por tanto, pese a la declaración inicial, con una interpretación del precepto constitucional menos limitada a la proyección en el cumplimiento penitenciario, la declaración de este artículo es un principio que puede utilizarse también para el rechazo a las penas de prisión de larga duración y, actualmente, tras su incorporación, para discutir el acomodo constitucional de la prisión permanente revisable ${ }^{14}$ e incluso, en lo que nos ocupa, la pertinencia de un instituto como el denominado "periodo de seguridad". Esto es, si la obligatoriedad en determinados casos, de cumplir una parte no susceptible de remisión, de privación de libertad, responde a estos presupuestos. La cuestión apunta entonces a si la resocialización es un derecho subjetivo susceptible de recurso de amparo ${ }^{15}$ o si es un principio general con vigencia en el ámbito del Derecho penal y penitenciario, en cuyo caso un precepto penal podría considerarse contrario a la CE por no dirigirse a tal finali$\mathrm{dad}^{16} \mathrm{u}$ obstaculizarla gravemente ${ }^{17}$.

11 Vid. COBO DEL ROSAL M. /BOIX REIG, J., "Derechos fundamentales del condenado, reeducación y reinserción social”. Comentarios a la legislación penal. Tomo I., Derecho penal y Constitución. Madrid, 1982, pág. 219.

12 Vid., en tal sentido, GARCÍA ARÁN, M., Fundamentos y aplicación de penas y medidas de seguridad en el Código penal de 1995. Navarra, 1997, pág. 34 y ÁLVAREZ GARCÍA, J., Consideraciones sobre los fines de la pena en el ordenamiento constitucional español. Granada, 2001, pág. 33.

13 Señala la STS 4490/1995 de 18 de mayo (La Ley 14522/1995), que en la medida que la constitución no hace distinción, la finalidad esencial debe procurarse en el momento legislativo (fijación por la ley de la pena que se atribuye al delito), en el ejecutivo de cumplimiento de la pena dentro del sistema penitenciario y en el judicial al señalar en la sentencia la pena correspondiente, y en relación a un supuesto de acumulación de condenas. En la misma línea, las SSTS 5920/1996 de 18 de julio (La Ley 854/1996) en un supuesto de redención de penas por trabajo y 7236/2002 de 6 de julio, declarando que el art. 25.2 CE tiene un alcance genérico.

14 Recientemente, no obstante, la STC 169/2021 de 6 de octubre (La Ley 179757/2021) ha declarado que esta pena no contradice el art. 25.2 CE (siete votos frente a tres).

15 A veces se ha invocado la cuestión de los permisos de salida (su negativa) o el rechazo a la progresión en grado como quiebra del art. 25.2 CE por ser materia que entronca con el derecho a la reeducación y reinserción social. El $\mathrm{TC}$, en tales casos, ha aplicado una reiterada doctrina considerando que, del contenido de la función resocializadora no se deriva un derecho subjetivo para el individuo, ni un derecho fundamental susceptible de amparo, sino un mandato dirigido al legislador. STC 115/2003 de 16 de junio (La Ley 12665/2003). Considera que se trata de cuestiones de legalidad ordinaria.

16 La STC 28/1988 de 23 de febrero (La Ley 314/1988) y otras posteriores siguiendo su doctrina, estableció en su día que el art. 25.2 CE no confiere, como tal, "un derecho amparable que condicione la posibilidad y la existencia misma de la pena”. El pronunciamiento deja claro que no se trata de dotar a la reinserción de un sentido positivo y que el penado pueda exigir el logro de los objetivos de integración y reeducación tras el cumplimiento de la pena, resaltando el aspecto negativo de no obstaculización de dicho objetivo.

17 Uno de los casos más reiterados, está relacionado con la orden de traslado del Centro penitenciario donde está ingresado a otro distinto, por entender que viola su derecho a la reeducación y reinserción social por la pérdida de vínculos personales y familiares, provocando un aislamiento afectivo y cultural que pone en peligro la función resocializadora de la pena. Vid., sin embargo, la STSJ de Madrid (La Ley 184440/2010) confirmando la teoría constitucional al declarar que el objetivo de la reeducación no es el único fin admisible de las penas privativas de libertad y que tiene como destinatario al legislador en primer lugar y, después, a la Administración penitenciaria. 
En general, resulta patente que los fines que se le han atribuido en cada momento a las penas han sufrido una evolución que sigue, en cierto modo, la ley del péndulo desde posiciones más retributivas hasta las más ajustadas a una prevención especial positiva. Sin embargo, las tesis más tradicionales en cierto modo vuelven cada cierto tiempo, revestidas o no de un nuevo aspecto y auspiciadas por determinadas corrientes políticas, sociales y también doctrinales. Basta analizar las últimas reformas legislativas en materia penal y penitenciaria en las que se observa un peligroso acercamiento a las tesis retributivas más alejadas del preventivismo.

En esta línea, ya la modificación operada por LO 7/2003, de 30 de junio, de cumplimiento íntegro y efectivo de las penas, introdujo las mayores reformas relativas a la ejecución de penas que se habían conocido hasta el momento, no sólo en lo que respecta al periodo de seguridad, sino también, y principalmente, en lo que concierne al límite máximo de cumplimiento que pasa a ser de 40 años en diversos supuestos ${ }^{18}$. Al tiempo establece, lo que no es menor, que los beneficios penitenciarios, los permisos de salida, la clasificación en tercer grado y el cómputo de tiempo para la libertad condicional se calcularán en atención a la totalidad de las penas impuestas en la sentencia, si como resultado de los límites impuestos por la regla del concurso real del art. $76 \mathrm{CP}$, la pena a cumplir resultase inferior a la mitad de la suma de las impuestas (art. 78.1 CP) ${ }^{19}$. En la medida, además, de que los límites concursales exigen conexidad entre los diversos procedimientos, como posibilidad de enjuiciamiento conjunto, el TS se ve obligado, en muchas ocasiones a rechazarla provocando con ello la existencia de condenas de más de treinta años de prisión ${ }^{20}$, ya que cuando son varias penas se cumplen sucesivamente por su respectiva gravedad.

Se incorporan, adicionalmente, periodos mínimos para acceder a los beneficios penitenciarios y se modifica todo el instituto de la libertad condicional ${ }^{21}$. Estos cambios implican una variación sustancial en la filosofía que inspira la LOGP que, fundamentada en el sistema de individualización científica, trata de salvar los obstáculos relativos a la

No existe, pues, ese derecho subjetivo a cumplir la condena impuesta en centros próximos a su domicilio. En el mismo sentido, STS 1219/2010 de 2 de diciembre (La Ley 2905448/2010). También se ha invocado la vulneración al derecho a la reeducación en relación con la acumulación de condenas y los límites establecidos en el art. 76 CP, cuyo techo máximo - superando los veinte años generales, alcanzando veinticinco, treinta o cuarenta años- se ha entendido que vulneraba la finalidad reeducadora. El Tribunal rechaza el argumento. Vid. Auto TS de 5 de marzo de 2009, (La Ley 15156/2009).

18 Si se cometen dos o más delitos de terrorismo, estando alguno castigado con pena de prisión superior a 20 años o habiéndose cometido dos o más delitos castigados con más de 20 años de prisión.

19 Asevera la Exposición de Motivos que "con esta regla y frente a supuestos de condenas de 100, 200 o 300 años, el delincuente cumplirá en la práctica de forma íntegra y efectiva el límite máximo de condena”. No obstante, el TS señala la necesidad de una motivación reforzada para ejercer esta facultad discrecional y justificar un retraso en la concesión de permisos y beneficios que supongan un acortamiento de la pena. Así, SSTS 18/2020 de 28 de enero (la Ley 1399/2020) y 217/2021 de 10 de marzo (La Ley 115000/2021).

20 El propio TS se ha pronunciado en contra de las penas excesivamente largas ya que no sirven a la resocialización, ni a la prevención general ni a la especial sino solo al envilecimiento del condenado. Abogando por la necesaria limitación de la pena de prisión, Vid. STS 12/2000 de 23 de enero en la que se alude a la "prohibición de tratos inhumanos o degradantes" (La Ley 3261/2000) o STS 5942/2003 de 7 de marzo, donde se advierte que "no puede conseguirse o es muy difícil la consecución del mandato constitucional de resocialización cuando se produce, en función de las circunstancias, una excesiva exasperación de las penas. La legalidad constitucional debe prevalecer sobre la ordinaria".

21 Así, en los casos de delitos de terrorismo o los cometidos en el seno de organizaciones criminales, podrá el JVP determinar la concesión de un tercer grado cuando reste por cumplir una quinta parte del límite máximo de cumplimiento de la condena impuesta y la libertad condicional cuando quede por cumplir una octava parte del citado límite. 
rigidez y escasa capacidad de atención a las circunstancias personales, propias de los sistemas progresivos - con un periodo de cumplimiento imperativo en cada una de sus fases- configurando un sistema que, incluyendo también una progresión en el retorno a la vida en libertad, atiende a la duración de la pena pero con criterios altamente flexibles atendiendo a la evolución del condenado (art. 63.3 in fine LOGP) poniendo en un lugar prioritario el tratamiento reeducador y haciendo hincapié en los recursos necesarios (de índole personal, educativos, laborales o sociales). Ello permitía que una persona pudiera ser clasificada inicialmente en tercer grado o tras un breve periodo en segundo grado de tratamiento. Lo anterior no significa, sin embargo, que con carácter general, condenas por delitos graves se reduzcan a una condena escasa o de pocos meses, accediendo con rapidez al tercer grado, pues los condenados a estas penas medias o largas, suelen agotar, en la mayoría de los casos, el tiempo de prisión preventiva, al menos su primer plazo, con lo que a la hora de su clasificación inicial habrá estado privado de libertad de forma ininterrumpida al menos dos años.

Toda esta batería de reformas penales acaecidas en el año $2003^{22}$, tuvieron como consecuencia necesaria el endurecimiento de las penas y de su ejecución, recibiendo de forma mayoritaria una valoración negativa por parte de la doctrina. ${ }^{23}$, sobre todo porque hasta ese momento no había fricciones importantes entre el CP y los textos competentes para regular la ejecución penitenciaria (La LOGP y su Reglamento), produciéndose ahora una relevante intromisión del texto punitivo en aquella legislación específica, tanto mediante la regulación del periodo de seguridad como requisito para la clasificación en tercer grado, las restricciones del art. $78 \mathrm{CP}$ o la regulación de la PPR con una serie de plazos tasados para obtener los permisos de salida, el tercer grado y la suspensión del resto de la pena, con criterios objetivos alejados de los individuales propios de la prevención especial desviándose del espíritu resocializador del sistema penitenciario implantado en la LOGP y produciendo importantes disfuncionalidades.

Respecto al periodo de seguridad implantado y en esta línea de reformas, para que las mismas tuvieran una coherencia intrasistemática, se debería haber modificado paralelamente el art. 72.3 LOGP que permite la clasificación inicial en tercer grado "siempre que de la observación y la clasificación correspondiente de un interno resulte estar en condiciones para ello", así como el art. 72.4 de la misma ley según el cual "en ningún caso se mantendrá a un interno en un grado inferior cuando por la evolución de su tratamiento se haga merecedor a su progresión" 24 , lo que además, hubiera resultado coherente con la finalidad última de la reforma que pretendía un endurecimiento de la ejecución y una aproximación al cumplimiento de la pena nominal.

22 En este proceso no tienen un papel secundario los sectores mediáticos que alentando un sentimiento de inseguridad, se hacía eco de ciertas resoluciones y la ejecución de las mismas en casos de penas de prisión por delitos de terrorismo. Fue inmediato (año 2002) el anuncio por parte del Gobierno (PP en ese momento) de la creación de los Juzgado Centrales de Vigilancia Penitenciaria y el endurecimiento de las penas para supuestos de terrorismo.

23 Vid., críticamente, Grupo de Estudios de Política Criminal, "Una alternativa a la actual política criminal sobre terrorismo", 2008 y DÍEZ RIPOLLÉS, J.L., “La evolución del sistema de penas en España: 1975-2003”. RECPC, 2006, pág. 12.

24 Como lo indicaba en su día CERVELLO DONDERIS, V., "Los fines de la pena en la LOGP". Jornadas en homenaje al XXV aniversario de la LOGP, Madrid, 2005, pág. 250., ESPINA RAMOS, J.A., "La reforma para el cumplimiento íntegro y efectivo de las penas: luces y sombras", Revista de derecho y proceso penal, $\mathrm{n}^{\circ}$. 11, 2004, pág. 27 y MANZANARES SAMANIEGO, J. L., "El cumplimiento íntegro de la penas", Actualidad penal, $\mathrm{n}^{\circ} 1$, 2003, pág. 213. 


\section{LA PRIVACIÓN DE LIBERTAD DE OBLIGADO CUMPLIMIENTO: LA IRRUPCIÓN DEL PERIODO DE SEGURIDAD}

El modelo de cumplimiento de la pena de prisión vigente en nuestro ordenamiento sigue un modelo de "individualización científica" que, al menos en teoría, supone la superación del anterior sistema progresivo clásico ${ }^{25}$ centrado en requisitos objetivos y temporales que permitía saber con más o menos exactitud el tiempo en que el interno iba a estar privado de libertad. Se exigía del interno que pasara por todos los grados penitenciarios y su evolución en los mismos iba a depender de su conducta y del tiempo transcurrido en prisión. La promulgación de la Ley Orgánica General Penitenciaria de 1979 (LOGP), supuso un cambio sustancial, consagrando en el art. 72 un sistema que, de carácter subjetivo, basa la progresión o regresión en las circunstancias personales del penado. Un modelo flexible que permite incluso la clasificación inicial del interno en el tercer grado de tratamiento, el más benigno y paso previo a la libertad condiciona ${ }^{26}$ que implica una semilibertad, siempre con criterios técnicos ${ }^{27}$. Se atiende, en este sentido, a las circunstancias individuales para concretar un programa particularizado de tratamiento, determinar su clasificación inicial en un determinado grado o el paso a uno superior o inferior con su correspondiente régimen diferenciado ${ }^{28} \mathrm{e}$, incluso, determinar su destino al tipo de establecimiento más adecuado $^{29}$. Por ello, la incorporación de criterios objetivos vinculados a la duración de la condena y la tipología delictiva para blindar una parte de la pena de prisión que debe cumplirse en el Centro penitenciario supone un claro retroceso que nos recuerda de nuevo al sistema progresivo que creíamos superado.

Por tanto, el modelo que podíamos denominar "régimen general de clasificación" en el que el interno no tiene que pasar necesariamente por cada grado, pudiendo acceder en la clasificación inicial a cualquiera de ellos (art. 73.2 LOGP), excepto a la libertad condicional (que, por lo demás ya no constituye un grado de cumplimiento, sino una forma de suspensión de la pena), desapareciendo los plazos mínimos de permanencia en cada grado $^{30}$, se ve acompañado por un "régimen especial" integrado por distintas excepcio-

25 El RD de 3 de julio de 1901 consagró en nuestro ordenamiento el sistema progresivo, dividiendo el cumplimiento de la pena en cuatro fases: periodo celular (7-12 meses), periodo industrial y educativo (la mitad del tiempo que quedaba por extinguir), periodo intermediario, y por último, el periodo de gracia y recompensa.

26 El desarrollo reglamentario de la LOGP del año 1981 (RD 1201/1981, de 8 de mayo) requería en su art. 251 una estancia mínima de dos meses de estancia real, en aquellos internos que no hubieran cumplido la cuarta parte de la condena, además de la existencia de criterios favorables de primariedad delictiva. Posteriormente, el R.D. 1764/1993 elimina tal exigencia de permanencia hasta que llegamos al sistema de "individualización científica" puro presente en el art. 104.3 del RP (R.D. 190/1996, de 9 de febrero de 1996) que sólo exige un tiempo de estudio suficiente y la concurrencia favorable de las variables intervinientes en el proceso de clasificación penitenciaria.

27 Vid. Art. 72.1 LOGP.

28 La clasificación requiere un estudio individualizado de la personalidad y del historial completo del interno. Se deberá tomar en consideración la duración de la pena, el medio al que retornará el interno cuando obtenga su libertad y los recursos, facilidades y dificultades existentes en cada caso y momento para el buen éxito del tratamiento. Vid. Arts. 62-64 LOGP y 102 RP.

29 También se permite crear programas personalizados que combinen elementos de varios grados (art. 100.2 RP). Vid. También el tercer grado restringido (art. 82 RP) o el internamiento en centro de deshabituación o educativo (art.182 RP).

30 Salvo la previsión temporal contenida en el art. 104.3 RP cuando señala que la posibilidad de realizar una propuesta de tercer grado respecto a un interno que no tenga extinguida la cuarta parte de la condena se subordina al transcurso del tiempo suficiente para obtener un adecuado conocimiento del mismo y concurrir en sentido favorable las variables intervinientes en el proceso de clasificación enumeradas en el art. 102.2 RP (especialmente el historial delictivo y la integración social del penado). Este criterio objetivo temporal (una cuarta parte de la condena) 
nes al régimen general ${ }^{31}$, incorporado esencialmente por la Reforma del CP operada por la LO 7/2003, de 30 de junio que se desdobla a su vez en distintas modalidades que, de forma obligatoria o potestativa, establecen restricciones temporales en el acceso al tercer grado mediante el denominado "periodo de seguridad" (arts. 36.2, 36.3 y 78 bis CP) que afecta tanto a la pena de prisión temporal como a la prisión permanente revisable (PPR) y que tiene mucho que ver, en su modalidad más rígida, con una determinada tipología de delitos ${ }^{32}$, conllevando un tiempo obligatorio de cumplimiento de la pena de prisión en régimen ordinario antes de acceder al régimen de "semilibertad" 33 .

De esta forma, la citada LO 7/2003 introduce por primera vez en nuestro ordenamiento a través de su art. 1 que modifica el art. $36 \mathrm{CP}$, el denominado en otros ordenamientos europeos ${ }^{34} \mathrm{y}$, específicamente en el francés, periodo de seguridad ${ }^{35}$ para casos de acumulación jurídica en casos de terrorismo. Significa, en síntesis, la imposibilidad de acceder al tercer grado penitenciario hasta tanto no se haya cumplido la mitad de la pena impuesta en aquellos casos en que ésta sea superior a cinco años y siempre y en todo caso, para los delitos de terrorismo y los cometidos en el seno de organizaciones criminales. No obstante, el JVP podrá acordar, mediante un procedimiento bastante tortuoso, el régimen general de cumplimiento.

Este régimen especial que dificulta el acceso al tercer grado estableciendo un límite temporal (en su origen obligatorio) para todos los delitos sancionados en una condena

escudado en la falta de tiempo de estudio, supone una concesión a la prevención general, que puede quedar desactivada puesto que se supedita a la evolución positiva del interno. Esta regulación deja sin apenas virtualidad la previsión del art. 104 del RP que establece las variables a tener en cuenta en supuestos de clasificación en tercer grado de internos que no tengan cumplida la cuarta parte de la condena, que sólo operaran cuando la pena impuesta sea inferior a cinco años o, cuando siendo superior, el JVP levante al penado el periodo de seguridad impuesto por el juez sentenciador en los casos en que es potestativo.

31 Analizando el doble sistema, ARRIBAS LÓPEZ, E., "Reflexiones en torno a los fines de la pena y a los regímenes de cumplimiento de la pena de prisión". Revista Poder Judicial, núm. 77, 2005, págs. 75 y ss.

32 Cuestiones estrictamente de ejecución de la pena que deberían haberse incorporado en la LOGP y RP. Vid. GONZALO RODRÍGUEZ, R.M., "Análisis del Código penal de 1995 tras la LO 7/2003, de 30 de junio de Medidas de Reforma para el cumplimiento íntegro y efectivo de las penas”. La Ley penal. Revista de Derecho penal, procesal y penitenciario,

33 Los antecedentes del periodo de seguridad para la pena de prisión podemos encontrarlos en la Ordenanza de Presidios del Reino de 14 de abril de 1834 donde se establecía la posible reducción de pena a partir del cumplimiento de la mitad de la pena y en sistema progresivo de Montesinos citado (Reglamento de 1901) que establecía el periodo intermedio, una vez cumplida la mitad de la pena. Existe en el ámbito de la Responsabilidad Penal de los Menores (LORPM 5/2000) en casos de internamiento en régimen cerrado que no puede modificarse hasta cumplido un año en casos de extrema gravedad (art. 10.1 b) o la mitad de la condena en los supuestos del art. 10.2 b) (en caso de determinados delitos y teniendo el menor 16 o 17 años), para poder hacer uso de las facultades de modificación, suspensión o sustitución de la medida.

34 Ciertamente, se trata de un instituto que también existe en países europeos y la reforma venía a igualarnos a ellos. Vid. al respecto, GARCÍA ALBERO R. / TAMARIT SUMALLA, J. M., La Reforma de la ejecución penal, Valencia, 2004, págs. 41-45.

35 El sistema francés prevé el "periodo de seguridad" para ciertos delitos previamente señalados, siempre que la pena sea igual o superior a diez años y afecta a todos los beneficios que recaen sobre la ejecución de la pena incluidos los permisos de salida. Dicho "periodo de seguridad" puede ser reducido o aumentado porque existe un periodo obligatorio y otro facultativo. En nuestro ordenamiento el "periodo de seguridad" es obligatorio y no susceptible de reversión -ni por ello de material reducción- en el caso de ciertos delitos. Vid. ARANGUEZ SÁNCHEZ, C. / ALARCÓN NAVIO, E., El Código penal, francés traducido y anotado. Granada, 2000. El otro referente dentro del continente se encuentra en Italia. En el art. 50 de la Ley 345 de 26 de julio de 1975, se impone el cumplimiento de la mitad de la condena para alcanzar el régimen de semilibertad (figura similar al tercer grado español), en el caso de condenas superiores a seis meses. Se prevé asimismo, cuando se trate de ciertos delitos de mayor gravedad, la necesidad de cumplir al menos, las dos terceras partes de la pena y cumplir ciertos requisitos legales. 
con pena de prisión superior a cinco años, en cuyo caso solo se podía acceder al régimen de semilibertad habiendo cumplido la mitad de la pena, se entendió, además, aplicable a condenas anteriores a su entrada en vigor, aunque, finalmente, únicamente a delitos cometidos con posterioridad a la entrada en vigor de la LO 7/2003

Pero, no sólo eso, en esta línea de incorporación de obstáculos, la mencionada LO 7/2003 propició también que el acceso al tercer grado quedase anudado a otros elementos objetivos y, por definición, ajenos a la evolución del tratamiento y el penado que se encuentran en la LOGP ${ }^{37}$ : la satisfacción de la responsabilidad civil (art. 72.5 LOGP) y la necesidad de mostrar signos inequívocos de haber abandonado los fines y los medios terroristas, y además hayan colaborado activamente con las autoridades si se tratara de "personas condenadas por delitos de terrorismo de la sección segunda del capítulo V del título XXII del libro II del Código Penal o cometidos en el seno de organizaciones criminales.

\subsection{El sentido político criminal de la figura}

Junto con otras medidas, la introducción del periodo de seguridad pretendía, según indica la EM de la Ley 7/2007, evitar que "la pena prevista por el Código penal y la fijada en la sentencia quede muy distante de la efectivamente cumplida" lo que afectaría negativamente a la eficacia de las penas, teniendo un mayor efecto preventivo aquella que se cumpla íntegramente porque "el mayor freno de los delitos no es la dureza de las penas sino su infalibilidad, de modo que la certeza de un castigo, aunque este sea moderado, surtirá más efecto que el temor de otro más severo unido a la esperanza de la impunidad o de su incumplimiento". Por tales motivos, el legislador decidió limitar el margen de flexibilidad a tenor de criterios preventivo- especiales en sede penitenciaria, decantándose claramente por la prevención genera ${ }^{38} \mathrm{e}$, incluso, por la prevención especial en su vertiente inociuzadora. Sin embargo, hay que recordar que resultan muy débiles los argumentos que contraponen el cumplimiento íntegro y efectivo de las penas con un régimen semiabierto que se materializa en la adquisición del tercer grado, como si ello dejara sin contenido o anulase

36 Vid. La Instrucción de la DGIP 2/2005 dejando claro este asunto o la STS 748/2006 de 12 de junio (RJ 2006/6305).

37 Este requisito se interpreta, para no infringir el principio de igualdad con los reclusos que carecen de recursos económicos, en un sentido subjetivo, esto es, en función de la voluntad y capacidad del interno y las garantías que permitan asegurar la satisfacción futura, tal y como se indica en la propia redacción del precepto y corrobora la Instrucción DGIP 2/2005. Que la exigencia de repudia de las actividades y petición de perdón pueda suponer la introducción de aspectos moralizantes, ha sido algo puesto de relieve por la doctrina. Vid. FARALDO CABANA, P., en FARALDO CABANA P. /PUENTE ABA L.M./BRANDARIZ GARCÍA, J. A., (coords.), Nuevos retos del Derecho penal en la era de la globalización, 2004, págs. 326 y ss. Y es que, en efecto, como apunta FUENTES OSORIO, J.L., puede tratarse de un criterio esencial para valorar la peligrosidad del terrorista y su grado de resocialización, pero "la renuncia a los fines, plasmada en el carácter obligatorio de la declaración de repudia de sus acciones terroristas y de petición de perdón a las víctimas, implica reformular la resocialización de modo que se entienda como como la imposición coactiva de la ideología dominante". Para no incurrir en un derecho penal de autor, la resocialización del terrorista debería limitarse a la constatación de que ha abandonado no sus objetivos sino los medios terroristas para conseguirlos. "Sistema de clasificación penitenciaria y el «periodo de seguridad» del art. 36.2 CP”, InDret, 2011, nº1, pág. 6.

38 En opinión de GONZÁLEZ PASTOR, C.P., esta previsión temporal no estaría en contra de la constitución suponiendo únicamente un "elemento de rigidez". "Análisis de la LO 7/2003. Examen de su constitucionalidad". Actualidad Penal, no 40, 2005, pág. 12. En el mismo sentido, ESPINA RAMOS, J. A., "La reforma para el cumplimiento íntegro y efectivo de las penas: luces y sombras", ob. cit., pág. 26, por cuanto las finalidades del art. 25.2 no son las únicas de la pena, y las posibilidades de reinserción no quedan excluidas por las facultades que se atribuyen al Juzgado de Vigilancia. 
la pena de prisión ${ }^{39}$, sino que más bien se apuesta por un planteamiento que parte de la idea de que es más justo- en el sentido retribucionista del término- y más eficaz desde el punto de vista preventivo -prevención general ${ }^{40}$ positiva- un régimen de cumplimiento más duro, al menos durante un tiempo y -negativa ${ }^{41}$ - con la advertencia de ejecutar la pena impuesta de la formas más severa y menos flexible posible, en cierto modo como una forma de venganza o de expiación de la culpa. Una renuncia explícita a la prevención especial en su vertiente positiva de resocialización como guía y seña del sistema penitenciario y una apuesta por su versión negativa (inocuizadora) y de defensa social, todo ello en clara oposición a lo establecido en el art. 25.2 CE, el art. 1 LOGP y el art. 110 RP porque el periodo de seguridad implica privar al interno de la posibilidad de reinserción durante el tiempo que dura, dado que no es posible ajustar el modo de ejecución a la evolución positiva del interno ${ }^{42}$ impidiendo la reeducación en libertad parcial con un aumento de las cuotas de confianza y, al mismo tiempo de responsabilidad volviendo a tener contacto con el entorno social que le pertenece.

Aún más, el periodo de seguridad no sólo es que abandone el fin resocializador, sino que lo obstaculiza gravemente afectando a la motivación del interno que carece de estímulos para someterse voluntariamente y participar de forma proactiva en el programa de tratamiento individualizado que se le ha diseñado, porque, en todo caso, tiene que esperar al cumplimiento de la mitad de la condena para alcanzar el régimen abierto ${ }^{43}$. Así, desde un punto de vista político-criminal, el establecimiento de un periodo de seguridad para obtener la clasificación en tercer grado, tratándose de penas superiores a cinco años va en detrimento de la reinserción y la rehabilitación social a favor de criterios preventivo generales positivos que en realidad enmascaran un neoretribucionismo ${ }^{44}$ aun cuando pre-

39 La doctrina ha recordado en numerosas ocasiones que los permisos de salida, el régimen abierto o la libertad condicional no comportan una reducción de la pena, siendo institutos que afectan a las condiciones de ejecución. Así, MURILLO RODRÍGUEZ, R.A., Modernas tendencias en el Derecho penitenciario: las propuestas del Derecho penitenciario mínimo. El "Derecho penitenciario de enemigo" y las reformas de 2003 en el ordenamiento jurídico- penitenciario español. Getafe, 2009, pág. 231.

40 Críticamente, GONZÁLEZ TASCÓN, M.M., "El periodo de seguridad" en ALVAREZ GARCÍA F.J. / GONZÁLEZ CUSSAC, J.L., (Dirs.) Comentarios a la reforma penal de 2010, Valencia, 2010, pág. 92.

41 Prevención general positiva, por cuanto busca reducir los niveles sociales de frustración punitiva y la sensación de falta de eficacia penal al tiempo que aumentar la confianza en la vigencia del sistema penal y los valores que tutela y prevención general negativa en la medida en que representa una intimidación a la generalidad de la población mediante la posible imposición de una pena ejemplar y de ejecución efectiva en un régimen de cumplimiento más duro, al menos durante un tiempo. Vid. MAQUEDA ABREU, M.L., "Crítica a la reforma penal anunciada" Jueces para la Democracia, no 47, 2003, pág. 8 y MUÑAGORRI LAGUIA, I., "Derecho penal intercultural y crisis del principio de soberanía", en PORTILLA CONTRRERAS G., Mutaciones de Leviatán. Legitimación de los nuevos modelos penales, Madrid, 2005, pág. 194, apuntando que esta reforma se utiliza como instrumento de comunicación con los ciudadanos para reforzar o recuperar la confianza institucional.

42 Más allá de la progresión del primer al segundo grado y los permisos de salida que correspondan en este estadio.

43 Vid, en este sentido, ACALE SÁNCHEZ, M., "Terrorismo, delincuencia organizada y sistema de penas", en FARALDO CABANA P. / PUENTE ALBA L M. / BRANDARIZ GARCÍA J.A. (coords.), Nuevos retos del derecho penal en la era de la globalización, Valencia, 2004, pág. 373.

44 Vid., enmiendas considerando la introducción del periodo de seguridad una medida claramente retributiva. Así, la intervención del diputado del Grupo Parlamentario Federal de Izquierda Unida, Sr. Rejón, (Sesión Plenaria núm. 223, 6 de marzo de 2003, Congreso de los Diputados), apuntaba que "contra lo que verdaderamente carga este Proyecto de ley orgánica del Gobierno del Partido Popular es contra el sistema de individualización científica, que implica entre otras cosas, la progresión y regresión en el tratamiento penitenciario" (Diario de Sesiones del Congreso de los Diputados, Pleno y Diputación Permanente, 6 de marzo de 2003, pág. 11862). En términos similares, la enmienda de supresión núm. 7, presentada por el diputado Sr. Puigcercós i Boixassa, del Grupo Parlamentario Mixto, al señalar que "la introducción de un nuevo apartado 2 en el artículo 36 del Código Penal, 
tenda edulcorarse con el pretendido "derecho del ciudadano a conocer con certeza cuál es la forma en que se van a aplicar las penas, a saber, en definitiva, en qué se va a traducir en la práctica, la pena o sanción impuestas" y supone, en cierto modo una regresión del sistema penitenciario de individualización científica al anterior sistema progresivo ${ }^{45} \mathrm{sin}$ que tenga visos de ser eliminado atendiendo a la política criminal de los últimos años que incide no sólo en el incremento punitivo sino en la dureza de la ejecución ${ }^{46}$.

En el sistema general de acceso a tercer grado, la duración de la pena era y es cuando se aplica, un dato o elemento subordinado al juicio sobre la personalidad y a la evolución del interno que se muestra como eje principal de la concesión. La incorporación del periodo de seguridad, invirtiendo el sistema, crea un modelo en el que el tiempo de pena cumplido se convierte en factor esencial relegando la evolución del interno a un plano secundario. Así, cuando la pena supere los cinco años la clasificación inicial en tercer grado o la progresión al mismo se desliga del tratamiento y su evolución pasa a depender del periodo de tiempo transcurrido y a la cuantía de la pena, elementos objetivos que representan una cierta vuelta al sistema progresivo ${ }^{47}$, suponiendo, además, una excepción a lo establecido en el art. 72.4 LOGP que prohíbe mantener a un interno en un grado

instituyendo un «período de seguridad», constituiría un paso definitivo en el proceso de liquidación del modelo instituido por la LOGP, una de las leyes más humanas del mundo pero que ha sido sometida a un acoso constante. De prosperar la propuesta del Gobierno, la custodia e inocuización de reclusos se erigirían en los objetivos principales de las prisiones..." (BOCG, Congreso de los Diputados, Serie A, Proyectos de Ley, núm. 129-7, 25 de marzo de 2003, pág. 28). En esa línea, la enmienda de supresión núm. 22, presentada por la diputada Sra. Lasagabaster Olazábal, del Grupo Parlamentario Mixto, en la que justifica su propuesta en atención al hecho de que con el art. 36.2 "se niega lo que constituye la piedra angular del sistema penitenciario, que es la individualización científica. Se abandona el diseño de la LOGP para volver al anterior sistema progresivo. Se niega, por tanto, que durante un período de tiempo establecido a priori, el sujeto pueda cumplir la pena de prisión en un régimen de semilibertad por haber evolucionado" (BOCG, Congreso de los Diputados, Serie A, Proyectos de Ley, núm. 129-7, 25 de marzo de 2003, pág. 32). Por el contrario, proponiendo el aumento de 5 a 8 años de condena para la aplicación del período de seguridad, el Grupo Parlamentario Catalán (CiU) -enmienda de modificación núm. 59,- “ya que la realidad penitenciaria nos muestra que los condenados a más de cinco años de reclusión son una gran mayoría de los penados y, en muchas ocasiones, no se utiliza la violencia en la comisión del delito (BOCG, Congreso de los Diputados, Serie A, Proyectos de Ley, núm. 1297, 25 de marzo de 2003, pág. 45).

45 El propio CGPJ consideró que la limitación del "principio de seguridad" da lugar a que ya no rija un "sistema de individualización científica, sino que el sistema se limita en función de razones de prevención general positiva".

46 Tendencia que viene ya de lejos. Así, el Anteproyecto de LO de reforma del CP de 21 de junio de 2006 establecía en el art. $94.3 \mathrm{CP}$ el acceso al tercer grado tras cumplir la mitad de la pena impuesta en caso de reos "reincidentes y habituales" en un giro inesperado en la política criminal que suponía actuar de forma especialmente grave sobre la delincuencia de corte marginal y sobre personas que con un bajo pronóstico de reinserción a priori, se considera predestinada a reingresar en prisión, abstracción hecha de la duración de la condena y de la propia naturaleza objetiva del delito cometido, en un claro atentado al principio de proporcionalidad. Vid., también, la Proposición no de Ley de 3 de junio de 2008 instando al cumplimiento efectivo de las penas impuestas por delitos sexuales y la modificación del art. 36 para penas superiores a cinco años impuestas por delitos contra la libertad e indemnidad sexual de menores de 13 años (proponía al tiempo, la eliminación del automatismo vigente en el momento para todas las penas superiores a cinco años). En sentido semejante, el Anteproyecto de reforma del CP de 2009 respecto a todos los delitos sexuales (Título VIII CP) que quedarían excepcionados de la posibilidad de vuelta al régimen ordinario.

47 En este sentido crítico, GARCÍA ALBERO, R., en GARCÍA ALBERO, R. /TAMARIT SUMALLA,J M., La reforma de la ejecución penal, Valencia, 2004, pág. 34. GRACIA MARTÍN, L./ALASTUEY DOBÓN, M. C., en GRACIA MARTÍN, L. (coord.), Lecciones de Consecuencias Jurídicas del Delito, $3^{\text {a }}$ ed., 2004, pág. 92; y CERVELLÓ DONDERIS, V., "Los nuevos criterios de clasificación penitenciaria" La ley penal: Revista de Derecho penal, procesal y penitenciario, $n^{\circ} 8$, 2004, pág. 12; BAUTISTA SAMANIEGO, C., "Periodo de seguridad y crimen organizado", Cuadernos de Derecho Judicial (Derecho penitenciario: incidencia de las nuevas modificaciones) n 22, 2006, pág. 148; LEGANÉS GÓMEZ, S., "Crónica de una sentencia anunciada: el periodo de seguridad" La ley penal: revista de Derecho penal, procesal y penitenciario, núm. 37, 2007, pág. 125; MOLINA GIMENO, F.J., "El periodo de seguridad; individualización judicial versus individualización penitenciaria en la 
inferior cuando por la evolución de su tratamiento se haga merecedor a su progresión. Al mismo tiempo, se contrapone al mandato de revisión cada seis meses de la clasificación, contenido en el art.105.1 RP. Estudio que, una vez alcanzado el segundo grado y existiendo una decisión favorable al tercer grado por parte de la Junta de Tratamiento, carece de operatividad durante el tiempo que dure el periodo de seguridad, si existe, salvo que esta previsión legal se interprete como un mandato de solicitud al JVP de la vuelta al régimen general, en caso de que sea posible en función del delito cometido ${ }^{48}$.

Si nos adentramos en las razones que llevaron al legislador a su incorporación podemos acudir a la EM de la propia Ley que apoya la reforma básicamente en el principio de seguridad jurídica de los ciudadanos (9.3 C.E.), garantizado por los principios de legalidad y tipicidad (9.3 y 25 C.E.). Lo que entiende por principio de seguridad jurídica, es el "derecho a saber con certeza jurídica qué es delito y qué no lo es", el "derecho a saber cuál es la pena que le corresponde a la acción tipificada en la norma penal...", y consecuencia de éstos "el derecho del ciudadano a conocer con certeza cuál es la forma en la que se van a aplicar las penas, a saber en definitiva, en qué se van a traducir en la práctica la pena o sanción impuesta". El argumento resulta, cuanto menos curioso, realizando una interpretación muy forzada y hasta perversa del citado principio destinado al penado que es consciente de que no se le va a permitir acceder en un tiempo al régimen de semilibertad ${ }^{49}$ como si ello no fuese cumplimiento de la pena.

En realidad se utilizan los términos de un modo impropio, la seguridad jurídica implica que un sujeto pueda conocer fehacientemente y con anterioridad a la realización de una conducta que ésta se encuentra prohibida y cuáles serán las facultades de intervención estatal y consecuencias jurídicas anudadas a la misma y que será ejecutada conforme a lo dispuesto en la Ley, pero en ningún caso implica el derecho del ciudadano a conocer el tiempo exacto que va a pasar en régimen cerrado ${ }^{50}$. Tal vez el legislador quisiera referirse a la necesidad de establecer reglas para unificar los amplios márgenes de discrecionalidad que se observan en el ámbito del cumplimiento de las penas, aunque desde luego ello no es en sí mismo negativo sino que forma parte de la esencia de la ejecución penitenciaria, por estar íntimamente unida a la individualización ${ }^{51}$. Siempre se había pensado que la seguridad jurídica, hablando de penas, era fundamental para el penado que es quien tienen que cumplir la condena más que para el resto de la sociedad, pero ahora se da una vuelta al concepto y se da más importancia a que los ciudadanos sepan cómo se va a cumplir las penas.

ejecución de las penas graves”, Diario La Ley, núm. 6966, 2008, pág. 1436 y MURILLO RODRÍGUEZ, R. A., Modernas tendencias en el Derecho Penitenciario ..., ob. cit., pág. 232.

48 En tal sentido queda patente, tal y como se puso de relieve en relación con el Anteproyecto de la LO7/2003, que se trata de medidas excepcionales al régimen general penitenciario y que, por lo mismo y para evitar desajustes, debían haberse recogido en la LOGP y su Reglamento. Vid. MANZANARES SAMANIEGO, "El cumplimiento íntegro de la penas", Actualidad penal $n^{\circ}$ 1, 2003, pág. 214. Véase también al respecto ACALE SÁNCHEZ, M., "Terrorismo...", ob. cit., pág. 359 y BACH FABREGÓ/GIMENO CUBERO, "Clases y contenido de penas y ejecución de las penas", en QUINTERO OLIVARES (Dir.), La Reforma Penal de 2010: análisis y comentarios, 2010, pág. 85 .

49 GARCÍAALBERO, R. lo consideró una “manipulación de principios constitucionales”. La reforma de la ejecución penal, ob. cit., pág. 35 .

50 En este sentido también, ACALE SANCHEZ, M., "Terrorismo...", ob. cit., pág. 350.

51 Y cuando esa discrecionalidad roce la arbitrariedad o la ilegalidad, existe un sistema de recursos, la potestad disciplinaria de la propia Administración' y, en último extremo, el delito de prevaricación. 
Con tales argumentos, lo que se consideró una loable flexibilidad cuando se aprobó la LOGP para proporcionar la mejor respuesta a cada caso de forma individualizada $\mathrm{y}$ alineada con el fin resocializador de la pena pasa a considerarse un amplio margen de discrecionalidad que se debe suprimir ${ }^{52}$ o atemperar ${ }^{53}$ porque, finalmente se evidencia una gran desconfianza no sólo en el juzgador quien en ciertos casos debe imponer ${ }^{54}$ este blindaje temporal imperativamente, sino, principalmente, en las funciones que desarrolla la Administración penitenciaria que, de algún modo, debe hacer de brazo ejecutor de lo juzgado y de la pena impuesta mediante el efectivo cumplimiento de la misma (parte de ella en régimen ordinario).

Se configura así el periodo de seguridad como una nueva forma de individualización judicial ${ }^{55}$ de la pena pues la consecuencia directa de la cantidad de pena impuesta y el delito cometido será determinante para que le sea de aplicación o no el periodo de seguridad. En segunda instancia, esta nueva forma de individualización judicial dará lugar a una segunda y posterior individualización penitenciaria en la que se valorará e informará al Juez de vigilancia sobre las posibilidades de levantar el periodo de seguridad. Con ello se logra mitigar lo que se ha denominado como uno de los puntos más criticables del cumplimiento de las penas de prisión: a arbitrariedad con la que la Administración penitenciaria concede el tercer grado minusvalorando el fundamento culpabilísimo de la pena y sus fines de prevención general ${ }^{56}$.

Respecto a la denunciada arbitrariedad, es cierto que el sistema permite la distinta valoración de las variables intervinientes en el proceso de clasificación, pero debemos poner de relieve que la discrecionalidad reglada (no confundir con la arbitrariedad que lesiona el principio de legalidad) va unida a la ejecución penitenciaria. Y en esa discrecionalidad, juegan conceptos jurídicos indeterminados que serán valorados por la Administración penitenciaria, y en última instancia, por los JVP, amparados por el principio de independencia judicial (art. 117.1 C.E.). El temor a que el tercer grado deje vacío de contenido las condenas, pero esta posibilidad se ve neutralizada por el hecho de que el art. 107 R.P, obliga a que las resoluciones clasificatorias en tercer grado sean puestas

52 Vid., en este sentido crítico, LÓPEZ PEREGRIN, C., “¿Lucha contra la criminalidad mediante el cumplimiento íntegro y efectivo de las penas?”. Revista Española de Investigación Criminológica, http://www.criminología.net, 2004, pág. 6.

53 Sin embargo, es curioso que la flexibilidad que permite la adaptación del modo de cumplimiento puede discurrir en dos direcciones: la más restrictiva que implica el régimen cerrado, sustentado en un mayor aislamiento y pérdida de beneficios y la otra que camina hacia el régimen abierto y la suspensión del resto de la condena o libertad condicional. Sin embargo, la reforma sólo consigue limitar la discrecionalidad, en la segunda dirección que concede mayores cuotas de libertad al interno con una finalidad preventivo especial positiva, pero no la primera. Así, JUANATEY DORADO, C., "La Ley de medidas de Reforma de las penas y los principios constitucionales del Derecho penal”. La Ley de Derecho Penal, Procesal y Penitenciario, nº 9, octubre de 2004, pág. 1663.

54 También sobre los jueces de vigilancia penitenciaria, Jueces centrales de instrucción, Audiencias provinciales y audiencia Nacional que ejercen el control sobre la administración penitenciaria

55 Así lo indica MOLINA GIMENO, F., "El periodo de seguridad; individualización judicial versus individualización penitenciaria en la ejecución de las penas graves" Diario La Ley, nº 6966, 12, junio, 2018, pág. 4

56 MANZANARES SAMANIEGO, J.L., "El cumplimiento íntegro y efectivo de las penas", Actualidad penal, n 1, 2003, págs. 206 y 207. En el mismo sentido, entendiendo que el motivo principal de la reforma de 2003 era superar la impresión de arbitrariedad de la Administración, SOLAR CALVO, M-P., "Consecuencias de la Ley Orgánica 7/2003 en el ámbito penitenciario", Diario La Ley 7238, D-279, 2009, págs. 1662 y ss. Insistiendo también en el sentimiento de desconfianza hacia la Administración penitenciaria y los JVP, RODRÍGUEZ YAGÜE, C., "El modelo penitenciario español frente al terrorismo", La Ley penal: revista de Derecho penal, procesal y penitenciario, núm. 65, 2009, pág. 66. 
de manifiesto al Ministerio Fiscal en los tres días siguientes de la fecha de su adopción. Esta garantía, no obstante, puede advertirse insuficiente para garantizar la intervención jurisdiccional si tomamos en consideración la naturaleza del Ministerio Fiscal en España, impregnado por el principio de jerarquía (124 C.E.) y la clara dependencia de las Instrucciones proporcionadas por el Fiscal General del Estado. En este sentido, podría considerarse preferible la dependencia de la Ley, que a fin de cuentas es el resultado de la soberanía popular, que de indicaciones de carácter meramente administrativo ${ }^{57}$.

Con esta previsión que obliga al cumplimiento de una parte de la pena de prisión en régimen ordinario ${ }^{58}$, se evita la aplicación del régimen abierto hasta que se haya ejecutado un periodo mínimo en el Centro penitenciario, tratándose de delitos graves. Durante este periodo priman, claramente, consideraciones de prevención general sobre aquellos otros fines de prevención especial positiva, sobre la base de que, si el condenado por un delito de esta entidad pudiera acceder al tercer grado desde el inicio de la condena, se resentiría el sentimiento de vigencia del ordenamiento jurídico porque, como señala la EM de la Ley que introduce esta cláusula, la pena fijada en la sentencia quedaría muy distante de efectivamente cumplida ${ }^{59}$ y se justifica atendiendo al principio del derecho de los ciudadanos a la seguridad jurídica (art. 9.3 CE) entendida esta como "suma de certeza y legalidad, jerarquía y publicidad normativa, irretroactividad de lo no favorable e interdicción de la arbitrariedad"60. De esta forma, lo que se consideró positivamente una necesaria flexibilidad cuando se aprobó la LOGP para ofrecer mejor solución al caso concreto y consecuencia necesaria del fin resocializador de la pena, se considera a partir de ese momento de reforma, un amplio margen de discrecionalidad a combatir ${ }^{61}$. Y eso se utiliza veladamente para justificar la introducción de mecanismos que acorten la discrecionalidad de la Administración penitenciaria a la hora de la ejecución de la pena de prisión.

En este sentido, en el fondo subyace una gran desconfianza en los órganos administrativos penitenciarios a quienes corresponde aprobar la clasificación de los internos ${ }^{62}$ $\mathrm{y}$, en último extremo, en los órganos jurisdiccionales que ejercen el control sobre sus actuaciones (JVP, fundamentalmente) y se decide a establecer límites a esa discrecionalidad que parece entenderse más bien como arbitrariedad ${ }^{63}$, potenciando el cumplimiento

57 Considerando, en este sentido, positiva la introducción del periodo de seguridad, ESPINA RAMOS, J.A., "La reforma para el cumplimiento íntegro y efectivo de las penas: luces y sombras”, ob. cit., pág. 27.

58 Vid., en sentido positivo, el Informe del CGPJ al Anteproyecto de la Ley Orgánica de medidas de reforma penal para el cumplimiento integro y efectivo de las penas, pág. 12. Pues "la comunidad no entendería que el autor de un delito grave pudiera acceder a un régimen abierto desde el inicio de su condena y, en consecuencia, el sentimiento de vigencia del Ordenamiento Jurídico podría resentirse"

59 Hablando de un auténtico "vaciamiento de la pena", MANZANARES SAMANIEGO, J.L., "La orientación de las penas privativas de libertad hacia la resocialización del reo". La Ley, 5215/2010, pág. 6, pues aun cuando concurrieran las otras variables intervinientes en el proceso de clasificación "primariedad delictiva, buena conducta o equilibrio personal" y porque el Reglamento actual obliga en el art. 104.3 a que transcurra el "tiempo de estudio suficiente para obtener un adecuado estudio".

60 STC 179/1996.

61 Vid. LÓPEZ PEREGRÍN, C., “¿Lucha contra la criminalidad mediante el cumplimiento íntegro y efectivo de las penas?” Revista de Investigación Criminológica (criminet.net). Madrid, 2004, págs.1 y ss.

62 En este sentido, JUANATEY DORADO, C., "La Ley de medidas de Reforma...", ob. cit., pág. 7.

63 Existe un temor a que el tercer grado deje vacío de contenido las condenas, pero esta posibilidad se ve conjurada por el hecho de que el art. $107 \mathrm{RP}$ obliga a que las resoluciones clasificatorias en tercer grado sean puestas de manifiesto al Ministerio Fiscal (si bien sería deseable la intervención del JVP). Considerando que la intervención del Misterio fiscal no es suficiente por el principio de jerarquía que le guía, LEGANÉS GÓMEZ, S. "El periodo de seguridad 10 años después de la LO 7/2003, de 30 de junio, de cumplimiento íntegro y efectivo de las penas". 
íntegro de las penas ${ }^{64}$. Se olvida, no obstante, que el propio sistema vigente de individualización científica ya cuenta con mecanismos suficientes para corregir las decisiones que pudieran tomarse erróneamente por parte de la Administración, en concreto los filtros establecidos para una propuesta de tercer grado. Sin embargo la imparable expansión del derecho penal se ve amparada por una palpable quiebra de la división de poderes y una tendencia real dirigida al control político de la independencia judicial ${ }^{65}$, sobretodo reduciendo el arbitrio decisorio de la Administración y el JVP.

En toda la regulación y la justificación que la acompaña, cabe apreciar la influencia del denominado Derecho penal del enemigo, según el cual, determinados delincuentes pierden parte de sus derechos en atención a la gravedad del delito cometido lo que se alinea con la ola de neoconservadurismo que entiende la justicia y los fines de la pena en clave retribucionista. Se olvida también que la obtención del tercer grado no supone en todo caso una excarcelación precoz, pues en muchos casos este grado se concede en la modalidad restringida (art. $82 \mathrm{RP}$ ) permitiendo a los internos asistir a programas formativos que no existen en la oferta del Centro penitenciario o por la imposibilidad de desempeñar un trabajo en el exterior. En otras ocasiones el acceso al tercer grado conlleva el internamiento en un centro específico de rehabilitación (art. $182 \mathrm{RP}$ ) público o privado y siempre que no se abandone el tratamiento. Al final, parece que el legislador no se fía del amplio margen de maniobra que le queda a la Administración penitenciaria y bajo la peculiar versión del principio de seguridad jurídica decide el cumplimento "integro" de las penas en determinados casos. Hay que recordar, sin embargo, que no se trata cumplimiento "efectivo" sino de cumplimiento en régimen ordinario, lo que significa físicamente en el centro penitenciario.

Cierto es, y debe destacarse, que la Reforma de 2010 retoma en cierto modo el espíritu individualizador, suavizando el tratamiento del periodo de seguridad en la generalidad de los casos, que pasa a convertirse en algo potestativo para el Juez o Tribunal salvo en los casos en que la pena sea impuesta por una serie de delitos que enumera: delitos relativos a organizaciones y grupos terroristas y delitos de terrorismo; delitos cometidos en el seno de una organización o grupo criminal, delitos del art. 183 (abusos y agresiones sexuales a menores de 16 años) y, finalmente, delitos del cap. V del título VII, cuando la víctima sea menor de trece años ${ }^{66}$.

Por tanto, a tenor de lo expuesto, el tratamiento resocializador que pretende estructurarse a través del sistema de individualización científica, que por lo demás hay que recordar también atiende entre otras variables a la gravedad de la pena impuesta pero sin condicionar completamente la clasificación y que determina su régimen carcelario, presenta graves quiebras y recortes cuando se establecen periodos de seguridad para logar el último grado de cumplimiento en lo que no es sino un enmascaramiento de un

La Ley penal, n 104, septiembre-octubre 2103, pág. 5 y MARTÍNEZ ZANZUNDO, C., "El periodo de seguridad: génesis y evolución. ¿una vuelta al sistema progresivo?”. Revista Electrónica de Doctrina y Jurisprudencia, 2006, pág. 6.

64 Hay que recordar, no obstante, que el cumplimiento efectivo no excluye estar en tercer grado. Solamente no se produce tal cumplimiento en caso de indulto total o parcial.

65 Así lo pone de relieve, RIOS MARTÍN, J, "Reflexiones sobre la LO 7/2003 (La Ley 1123/2003): incremento de la violencia punitiva". Revista de Derecho penal y criminología, 2a época, nº extraordinario 2, 2004, pág. 106.

66 No se entiende bien la referencia a los trece años cuando las conductas son todas referidas a menores de edad (18) y la edad para consentir en materia sexual es desde la Reforma de 2015, 16 años. Por lo demás son conductas que, en su mayoría, contemplan una pena inferior o igual en su límite máximo a los cinco años. 
neoretribucionismo o hacen imposible el acercamiento progresivo a la sociedad mediante el blindaje de penas de muy larga duración sin posibilidad de obtención no ya solo del tercer grado, ni aun de permisos de salida. Pareciera que el legislador penal no cree en el mandato constitucional considerando, por el contrario, que las posibilidades que ofrece el principio de individualización científica minusvalorara el fundamento de culpabilidad que rige la imposición de una pena y sus fines de prevención general, tanto en su vertiente intimidatoria como de reafirmación del Derecho.

\subsection{Modalidad genérica, agravada y excepcional del periodo de seguridad}

La regulación que presenta el periodo de seguridad en el CP permite distinguir dos modalidades: la genérica contemplada en el art. 36.2 CP primer inciso (potestativo y con posibilidad de regreso al régimen general) y la agravada prevista en el art. 36.2, tercer inciso en la que no es posible la vuelta al régimen general de ejecución de la pena y es de obligada imposición cuando se trate de los delitos enumerados. Finalmente, la modalidad excepcional (art. 36.3 CP) es la prevista para septuagenarios y enfermos muy graves.

\subsubsection{Modalidad genérica}

La LO 5/2010 suavizó de algún modo la gravosidad de este instituto que pasa a ser algo de posible imposición a discrecionalidad del juez o tribunal sentenciador, algo que es remarcado por la EM de la citada Ley cuando afirma que se "elimina el automatismo hasta ahora vigente, introduciendo un mecanismo más flexible que permita a los jueces y tribunales adecuar la responsabilidad criminal a la gravedad del hecho y a la responsabilidad del delincuente" añadiendo que tal remodelación "garantiza la primordial finalidad constitucional de la pena, la resocialización" $"$.

En efecto, la no imperatividad del periodo blindado de cumplimiento en centro penitenciario rema a favor de los fines preventivo especiales, sin embargo, llama la atención en esta primera modalidad que la facultad de exigir un periodo de seguridad para progresar al tercer grado de tratamiento se atribuya al Juez o Tribunal sentenciador que no dispone de más información sobre el sujeto que la recogida en el procedimiento penal por el que se le ha condenado a esa pena grave para valorar la adecuación de una figura que afecta al cumplimiento penitenciario. No parece que el fallo de tribunal sea el lugar adecuado para tomar una decisión que requeriría analizar la evolución del sujeto una vez iniciada la ejecución porque se corre el riesgo de fundar la misma en criterios exclusivamente de prevención general. De esta suerte, el Tribunal sentenciador viene a suplir la labor de los equipos técnicos de IIPP, máxime cuando no se citan los criterios que se deben tomar en cuenta para adoptar tal decisión en el momento de la imposición de la pena.

Lo más confuso del precepto recogido en el art. 36.2 es que, al tiempo que se quiere objetivizar el proceso, no se establece ningún parámetro que sirva de guía al sentenciador, bien sea la gravedad del hecho, la peligrosidad del sujeto o cualquier otro factor significativo, aunque ello al tiempo comportaría una cesión (ya clara) al ordenamiento penitenciario en detrimento del orden penal y, de este, al control judicial haciendo "ejecutar lo juzgado".

67 Sin que por otra parte, continúa, "ello comporte detrimento alguno en la persecución por el Estado de otros fines legítimos de la misma" 


\subsubsection{Penas superiores a cinco años}

El periodo de seguridad rige para supuestos en los que, según reza el art. $36.2 \mathrm{CP}$, pfo. $2^{\circ}$, "la pena de prisión impuesta" sea superior a cinco años ${ }^{68}$. El cómputo temporal de lo prescrito no presenta dificultad alguna cuando se trata de una única pena impuesta en un solo procedimiento por un solo delito, circunstancia en la que bastará comprobar si aquella supera los cinco años, en cuyo caso se podrá imponer dicho periodo de cumplimiento blindado que se sitúa en la mitad de la pena. El panorama se vuelve más complejo cuando están presentes varias penas y/o condenas, diferenciación terminológica que resultará fundamental a estos efectos.

La interpretación del tenor literal de la ley ha dado lugar a distintas etapas aplicativas, por cuanto no queda explicitado si el periodo de seguridad viene en aplicación potestativa (o imperativa en el caso de la modalidad agravada) tratándose de penas individuales superiores a cinco años o si también cuando la suma de las mismas supera esa cuantía.

Así, en un primer momento, y en una clara interpretación en contra del reo aunque acorde con la ratio legis que creaba el periodo de seguridad como medida preventivo general $^{69}$, las Instrucciones de la DGIP 9/2003 y 2/2004, a pesar de que ello excedía claramente de la literalidad del precepto penal consolidaron la interpretación según la cual se debían tener en cuenta todas las penas o la refundición de las condenas que el sujeto estuviera cumpliendo, indicándose que "en los supuestos en los que el penado cumpla una pena de más de cinco años o varias que sumadas aritméticamente o refundidas excedan de esta duración, será necesario que el interno tenga cumplida la mitad de la condena o condenas, con independencia de que éstas vengan impuestas en una o varias causas o procedimientos"70. Todas las propuestas de clasificación inicial o progresión a tercer grado indicarán expresamente el total de la condena impuesta en la causa o causas penadas que se encuentre cumpliendo, así como la fecha de cumplimiento de la mitad de ellas. Todo ello en clara contradicción con el principio de legalidad.

Con posterioridad, la Instrucción DGIP 2/2005, en un radical cambio de criterio, opta por considerar la duración de la pena estricta, teniendo "en cuenta la pena o penas impuestas consideradas de manera individual ${ }^{71}$; es decir, que en los supuestos en los que

68 La Comisión técnica de Reforma del sistema de penas proponía que, para poder ser aplicado el régimen general, el penado hubiera cumplido un año de pena. Vid. VILLARERIEL PRESENCIO, L., "La Comisión técnica de reforma del sistema de penas y la reforma penal del año 2003". Diario la Ley, 4 de mayo de 2004, pág. 4. Estimando un cuarto de la pena para que así coincidiera con el plazo necesario de cumplimiento para los permisos de salida, RODRÍGUEZ ALONSO, A. /RODRÍGUEZ AVILÉS, J.A., Lecciones de Derecho penitenciario. Granada, 2011, pág. 33. Así figuraba también en el Anteproyecto que precedió a la LO 7/2003 aprobado por consejo de Ministros de 3 de enero de 2003, en armonía con el art. 47.2 LOGP que, de facto, ya operaba como periodo de seguridad aunque no exigido por el art. 104.3 RP, según el cual, para que un interno que no tenga extinguida la cuarta parte de la condena o condenas pueda ser propuesto para tercer grado, deberá transcurrir el tiempo de estudio suficiente para obtener un adecuado conocimiento del mismo y concurrir, favorablemente calificadas, las variables intervinientes en el proceso de clasificación penitenciaria enumeradas en el artículo 102.2, valorándose, especialmente, "el historial delictivo y la integración social del penado".

69 Las exigencias de prevención general se encuentran más presentes, en efecto, en una condena de 13 años como consecuencia de la suma de varias penas inferiores a cinco años que en un sujeto condenado a cinco años y seis meses.

70 Vid., al respecto, GONZÁLEZ DEL POZO, J.P., “Acotaciones al apartado $2^{\circ}$ del art. 36 del vigente Código Penal”, Cuadernos de Derecho Judicial (Derecho penitenciario II) núm. 17, 2003, pág. 602 y ARRIBAS LÓPEZ, E., "Reflexiones en torno a los fines de la pena..", ob. cit., pág. 82.

71 En el mismo sentido, la posterior instrucción DGIP 7/2010 de 14 de diciembre. 
el penado cumpla varias que sumadas aritméticamente o refundidas excedan de 5 años, pero que individualmente consideradas no excedan de este límite ${ }^{72}$, no le será de aplicación el periodo de seguridad"73.

Si según el discurso de la EM el periodo de seguridad está pensado para los delitos de mayor gravedad, esto es, lo que posean una pena de prisión superior a cinco años y como señala la Jurisprudencia, "es sabido, por aplicación del principio de legalidad, que la suma de delitos no convierte a cada uno de ellos en más grave, fuera de los concretos efectos de las circunstancias modificativas de la responsabilidad legalmente establecidas (reincidencia) o de los conceptos legalmente fijados en determinados delitos (habitualidad)" "74, no cabe otra interpretación que la apuntada, porque, además, como se señaló en su día acertadamente, el principio de unidad de ejecución recogido en el art. 193.2 RP está pensado exclusivamente para la libertad condicional ${ }^{75}$. Por tanto, cuando el art. 36.2 CP menciona expresamente "la duración de la pena" a diferencia de otros preceptos en los que el legislador alude en sentido diverso y con otro propósito a la "condena" de cumplimiento efectivo así, art. 76.1) o a "la suma total de las penas impuestas" (arts. 78 y 80.2. $\left.2^{\circ} \mathrm{CP}\right)^{76}$ se está refiriendo a la sanción que corresponde a una concreta infracción de la ley penal.

No obstante, un sector de la doctrinal, aduciendo una interpretación teleológica del art. 36.2 CP mantiene, probablemente con razón, que el legislador quiso que superado un determinado número de años de prisión el penado no pudiera ser clasificado en tercer grado hasta alcanzar la mitad de su cumplimiento, y para ello da igual que los citados años procedan de una pena única, varias acumuladas o refundidas ${ }^{77}$, tal y como proponía la primera Instrucción de la DGIP.

Partiendo de que regulación legal es notoriamente mejorable y del hecho de que hubiera sido necesario que la Reforma del CP hubiera venido acompañada de una previsión relativa al periodo de seguridad en la legislación penitenciaria que arrojase luz sobre esta y otras cuestiones que plantea esta figura, la interpretación que se ajusta a la letra de la ley (que en ningún momento alude a la "pena o el conjunto de las penas

72 La Circular1/2004de la Secretaría de Servicios Penitenciarios Rehabilitación y Justicia penal de la Generalitat de Cataluña, tras varios pronunciamientos judiciales, entre ellos el Auto de la AP de Madrid de 6 de mayo de 2004 y de la AP de Barcelona de 14 mayo del mismo año, consideró en sentido contrario y optando por una interpretación restrictiva de las restricciones a la individualización científica que "el precepto comentado hace referencia a la duración de la pena de cárcel impuesta sea superior a cinco años, y por lo tanto, parte de la pena individual, sin que ningún precepto autorice a considerar que se refiere a la suma de penas impuestas o a su acumulación conforme al art. 76.1 CP y sin que pueda hacerse una interpretación extensa en contra del reo que identifique la pena impuesta con el concepto de condena".

73 Optando también por la interpretación a favor del reo que conducirá a no aplicar el periodo de seguridad en los supuestos en los que las penas individuales no superaran los cinco años, ESPINA RAMOS, J.A., "La reforma para el cumplimiento íntegro y efectivo...", ob. cit., 2004, pág. 28.

74 AAP Barcelona 823/2005, de 1 de junio (JUR 2005\178882).

75 Vid. GARCÍA ALBERO, R., La Reforma de la ejecución penal, ob. cit., pág. 58 y el AAP Barcelona 823/2005, de 1 de junio (JUR 2005/178882).

76 Vid. AAP de Madrid 1180/2004, de 6 de mayo (ARP 2004/665). En contra, procediendo a la suma aritmética de todas las penas, la SAP Pontevedra 7/2006, de 6 de septiembre (JUR 2009\441531).

77 Así, TELLEZ AGUILERA, A., "La ley de cumplimiento íntegro y efectivo de las penas: una nota de urgencia”, La ley: Revista Jurídica española de Doctrina, Jurisprudencia y bibliografía, núm. 4, 2003, pág. 6. En el mismo sentido, GRACIA MARTÍN, L. BOLDOVA PASAMAR, M.A, ALASTUEY DOBÓN, C. Tratado de las consecuencias jurídicas del delito, Valencia, 2006, pág. 96, considerando que se ajusta de forma más evidente tanto a la finalidad de la ley como a la intención reguladora del legislador. 
impuestas" (o algo semejante) ${ }^{78}$ y aunque el legislador tuviera otros propósitos, es la que considera que cuando el art. 36.2 CP utiliza el término "pena" lo hace referido a la consecuencia jurídica del delito, a la respuesta del Estado ante la comisión de un ilícito penal, y no como equivalente a la "condena" que, en efecto, puede resultar de sumar distintas penas por diferentes delitos.

Por tanto, el núcleo de la cuestión no es otro que el sentido y alcance del término "pena" y su delimitación del término condena, para salvaguardar el principio de legalidad. En este sentido puede afirmarse que la pena "impuesta" es la consecuencia jurídica del delito, asignada por el titular del poder judicial en una sentencia, a una persona concreta, a través de un proceso penal de forma individualizada en función de la antijuridicidad y culpabilidad del sujeto. Por condena entenderíamos, en su caso, el sumatorio aritmético de las penas concretas e individualizadas después de aplicar, si fuera pertinente, las reglas concursales del art. 76 C.P ${ }^{79}$. Además, en una sentencia condenatoria, se incluiría no solo la pena o las penas principales, sino también las accesorias. Cualquier otra interpretación extensiva sería incompatible con el principio de legalidad, máxime cuando se trata de limitar un valor superior como es la libertad abarcando supuestos no contemplados expresamente en la ley.

A esta interpretación propuesta contribuye la propia redacción del artículo $76 \mathrm{CP}$ proporciona un argumento adicional dejando clara la distinción entre los términos pena y condena cuando alude a "el máximo de cumplimiento efectivo de la condena del culpable", en clara diferenciación de la sanción que corresponde a cada delito “...que no podrá exceder del triple del tiempo por el que se imponga la más grave de las penas en que haya incurrido". De manera que está limitación del tiempo de cumplimiento se convierte en lo que se denomina título de condena, que estará compuesta por la suma de distintas penas individuales, "declarando extinguidas las penas que procedan desde que las ya impuestas cubran dicho máximo". Queda claro, pues, que el concepto de "pena", es cualitativamente distinto al de "condena" $"$. La aplicación de las reglas penológicas del art. 76 del C.P no da lugar a una pena o condena nueva, únicamente establecen un límite de cumplimiento, un umbral a partir del cual, una vez que el condenado ha cumplido ese máximo, se le extinguen el resto de las penas que tuviera, pero mantiene intactas las mismas hasta ese momento $^{81}$. Refundidas las penas de prisión a efectos del cómputo para el acceso a la libertad condicional o los permisos o bien si las tuviera acumuladas por la aplicación de la regla del art. 76CP, si bien se integran en el quantum del título de condena, no pierden su autonomía como penas ${ }^{82}$.

78 Vid. art. 80.2 2 $2^{\text {a }} \mathrm{CP}$ cuando menciona los requisitos para dejar en suspenso la ejecución de la pena: "que la pena o la suma de las impuestas no sea superior a dos años"

79 Así, si una persona ha sido sentenciada a cuatro penas de tres años la condena efectivamente impuesta será de nueve años, por aplicación del art. $76.2 \mathrm{CP}$, pero las penas serán de tres años cada una.

80 La Jurisprudencia del TS avala la distinción entre pena y condena explicitándola refiriéndose al "título de condena", definido por el tiempo material de ejecución concreta sobre el penado después de aplicar las limitaciones derivadas de las normas concursales del art. 76 CP. Vid. STS de 17 de enero de 2002 (La Ley 14313/2002) admitiendo el recurso por inaplicación del art. $76 \mathrm{CP}$.

81 Así lo interpretó el Auto AP de Madrid de 12 de febrero de 1998 cuando al referirse a dicha cuestión estableció que "el límite de cumplimiento al triple de la pena mayor no es una pena nueva. Se trata pues, de un cumplimiento sucesivo hasta un límite, llegado el cual las no cumplidas, que son las restantes, quedan extinguidas. En este sentido también, el Auto JVP n 2 de Ocaña, de 15 de junio de 2004, en un caso en el que el penado cumplía penas de cinco y siete años, habiendo cumplido la mitad de la de siete hacía más de dos años y, revocando la resolución de IIPP.

82 Este es el posicionamiento que se plasmó en la XIII Reunión de Jueces de Vigilancia Penitenciaria. Valencia, marzo de 2004, al entender que el art. 36.2 CP utiliza la expresión "pena" frente al art. 193.2 RP que utiliza el 
Así, en supuestos en que en una misma sentencia se condena a la misma persona por distintos delitos a varias penas de prisión, o en aquellos otros en que se fija el cumplimiento efectivo de la condena conforme a las reglas del art. $76 \mathrm{CP}$, la interpretación estricta del art. 36.2 CP obligará a examinar si alguna de las penas de prisión impuestas supera los cinco años de duración o si, por el contrario, todas quedan por debajo de ese límite, pero sí la suma de las mismas lo supera En el primer caso será aplicable el periodo de seguridad y no lo será en el segundo.

Igualmente, y en apoyo de lo anterior, el art. 193.2 RP establece que "cuando un penado sufra dos o más condenas de privación de libertad, la suma de las mismas será considerada como una sola condena a efectos de aplicación de la libertad condicional", el precepto se refiere a condenas y no a penas y además porque regula un supuesto específico como es el de la libertad condicional que no resulta equiparable al régimen en que se cumple la pena.

La consecuencia práctica de todo lo anterior es que el periodo de seguridad no puede imponerse si, al menos una de las penas impuestas no fuera superior a cinco años de prisión teniendo en cuenta que el art.36.2 CP no se refiere en su dicción a la dimensión de la condena, ni a la suma de las penas impuestas, sino, exclusivamente, a la "pena impuesta" y la necesidad de interpretar restrictivamente una norma que supone una excepción al sistema de individualización científica y progresivo no lineal de cumplimiento de la pena que establece la LOGP en el art. 72.1.3 y. 4. Por debajo de tal límite, o si no se adopta dicho periodo blindado, la Instrucción 6/2020 sobre "Protocolo de ingreso directo en medio abierto", establece las pautas de actuación que faciliten el ingreso directo -que sigue siendo posible- de las personas penadas para hacer posible "un régimen de vida más acorde con el derecho a la reinserción evitando el contacto con el régimen ordinario, aminorando el impacto y efecto desoscializador que supone el internamiento en un centro penitenciario" $" 83$.

término "condena". Criterio, acogido también por la Circular 1/2004 de la Secretaría de Servicios Penitenciarios, Rehabilitación y Justicia Juvenil de la Generalitat de Cataluña, así como por los Autos de la AP de Madrid y la de Barcelona de 6 y 19 de mayo de 2004, respectivamente (La Ley 106598/2004), puesto que se parte de una pena individual sin que ningún precepto autorice o se refiera a la suma de las penas impuestas o a su acumulación conforme al art. 76.1 CP, y sin que pueda hacerse una interpretación extensiva en contra del reo que identifique la "pena impuesta" con la "condena".

83 Con tal finalidad, deberán valorarse las siguientes circunstancias: "Presentación voluntaria; Condena no superior a 5 años; Primariedad delictiva/penitenciaria, no computándose a estos efectos ingresos anteriores como preventivo por la misma causa; Satisfacción de la responsabilidad civil, declaración de insolvencia o compromiso de satisfacción de la misma de acuerdo con su capacidad económica ;Antigüedad del delito superior a tres años y correcta adaptación social desde su comisión hasta el ingreso en prisión; Actividad laboral en el momento de la presentación o existencia de un proyecto vital acorde a sus circunstancias personales que le permita subvenir a sus necesidades. También se valorarán otras actividades, tales como educativas, voluntariado, etc., que puedan ser realizadas por la persona condenada durante el cumplimiento en tercer grado; Red de apoyo familiar y social bien integrada o en condiciones favorables que permitan el aval propio o autoacogida; En el caso de presentar adicciones relacionadas con la actividad delictiva, que se halle en tratamiento, en disposición de realizarlo o lo haya superado favorablemente. Con independencia de la posibilidad de realizar programa específico, de deshabituación u otros, en el contexto del régimen abierto una vez se produce la clasificación".

Formulada propuesta de clasificación inicial por la Junta de Tratamiento, se arbitrarán las medidas oportunas por la Dirección del centro para que la adopción de la resolución que proceda, así como de su efectos, puedan tener vigencia a la mayor celeridad, especialmente, cuando la propuesta de clasificación sea de tercer grado de tratamiento o, aún sin ser mayoritaria, incluya votos favorables a la clasificación en tercero. 
Más allá de esta posibilidad, la siguiente cuestión apunta directamente a cómo se debe determinar el periodo de cumplimiento cuando existen varias penas que superan esa cuantía, pues resulta primordial concretar con referencia a qué pena se determina la mitad para su obligado cumplimiento antes de poder acceder al tercer grado: ¿debería ser la mayor o la suma de todas? El cambio de criterio que supuso la Instrucción 2/2005 no conllevó un pronunciamiento a este respecto aunque pueda inferirse la solución. Tampoco las posteriores reformas del art. 36 (por LLOO 5/2010 y 1/2015) han previsto una solución expresa al respecto.

En primera instancia, podría considerarse que la utilización del singular que hace el art. 36 que se refiere únicamente a la "pena" y el dato de que la Instrucción DGIP 2/2005 se refiera únicamente a la imposibilidad de tener en cuenta la suma de las penas para entender sobrepasado el límite de los cinco años a efectos de que tenga virtualidad el periodo de seguridad, obliga a concluir que, por lo mismo, esta institución se debe ceñir a una pena superior a cinco años, desdeñando el resto aun cuando superen esta duración. Quedaría aún por determinar en tal caso si se elegiría a tales efectos como referencia la de mayor o menor duración.

Desde otra perspectiva, se puede defender que deben tomarse en consideración todas las penas superiores a cinco años (la Instrucción 2/2005 alude a la pena o penas impuestas, consideradas de manera individual) para cumplir con las expectativas preventivo generales que son el fundamento de este periodo de seguridad y que invita a determinar que la medición temporal ha de estar acorde con la suma aritmética de todas las penas superiores a cinco años ${ }^{84}$.

No obstante, como señala Fuentes Osorio, esta última solución estaría olvidando los límites existentes en el CP para la acumulación jurídica que, en sentido estricto, también tendrían que aplicarse al periodo de seguridad aunque no estén previstos de forma expresa para estos casos. En concreto, los límites establecidos en el art. $76 \mathrm{CP}$ "deben ser un referente para la medición de todos los plazos vigentes en el derecho penitenciario si no se quiere generar incongruencias. Su falta de respeto conduciría, por ejemplo, a situaciones en las que el periodo de seguridad podría tener una duración superior a la libertad condicional" ocasionando una grave incongruencia ${ }^{85}$.

En conclusión, lo más lógico y con coherencia sistemática es entender que se sumarán todas aquellas penas que sobrepasen el límite de los cinco años, siempre que el resultado de dicha adición no sea superior al que se obtienen mediante la aplicación de la regla concursal del art. $76 \mathrm{CP}^{86}$.

84 Dando un paso más y englobando todas las penas, siempre que una de ellas considerada individualmente supere los cinco años de prisión, ESPINA RAMOS, J.A., pág. 29, toda vez que el 193.2 RP (aunque referido al tiempo de libertad condicional) nos habla de que la suma de las diferentes condenas deberá considerarse como una sola a los efectos del cómputo del tiempo pues lo contrario resultaría incompatible con el sistema de individualización separado en grados.

85 Pone un ejemplo clarificador: si un sujeto ha sido condenado por un total de 35 años (tres delitos sancionados con 10,10 y 15 años), pero su condena máxima es de 20 años, entonces resultaría que si medimos el periodo de seguridad respecto a la adición de todas las penas superiores a 5 años sin límite, el interno obtendría antes la libertad condicional (15 años $-3 / 4$ partes de los iniciales 20 años-) que la posibilidad de acceder al tercer grado (17 años y seis meses). Si no se asumen límites se crea un régimen muy próximo al del art. $78 \mathrm{CP}$ para supuestos que, respecto a otros plazos, aparecen vinculados a lo establecido por el art. 76 CP. "Sistema de clasificación penitenciaria y el periodo de seguridad del art. 36.2 CP”, InDret, 2011, págs. 19 y 20.

86 En este sentido también, el citado AAP Barcelona 823/2005, de 1 de junio (JUR 2005/178882). 


\subsubsection{El periodo de seguridad cuando recae una nueva condena}

Es posible que sobre una persona interna ya clasificada en tercer grado recaiga una nueva sentencia condenatoria que conlleve una pena de prisión superior a cinco años. Ante tal situación caben, de nuevo, dos posiciones diferenciadas.

La primera solución a tales supuestos vino de la mano de la reiteradamente citada Instrucción 9/2003 que consideraba que si sucede que a un interno le recae una nueva condena de tal suerte que pasa a no tener cumplida la mitad de todas las condenas, la Junta de tratamiento procedería a revisar su clasificación con el fin de realizar una valoración actualizada de todas las variables del interno. En el caso de que el Juez de Vigilancia no hubiera efectuado con anterioridad pronunciamiento sobre la aplicación al interno del régimen general de cumplimiento, dicha revisión de clasificación se remitiría de forma preceptiva al Centro Directivo con sus informes complementarios.

Con una postura diferente a este respecto y en consonancia con lo anteriormente considerado cabe interpretar la pena en un sentido individual y autónomo, desdoblándose así nuevas opciones, según la duración de la nueva pena recaída. De este modo, si la nueva sanción fuese inferior a los cinco años y aun cuando al sumarse con la que actualmente se está ejecutando, superase el límite legal, debería mantenerse el tercer grado en tanto que la nueva pena no cumple por sí misma con el requisito de establecido en el art. 36.2 $\mathrm{CP}$ en cuanto a su duración. En este punto la cuestión resulta clara. No obstante, es posible que la nueva pena supere los cinco años, en cuyo caso surge la duda si estos hechos deben dar lugar a la regresión en grado o si, con otra visión, debe acudirse al pronóstico favorable de reinserción social y mantener el tercer grado si estuviera presente tal informe positivo. Esto último fue lo recomendado en la XIII Reunión de Jueces de Vigilancia Penitenciaria a la "procede instar a la Dirección General para que, en los supuestos de internos clasificados en tercer grado a los que llegue una nueva responsabilidad penal superior a los cinco años en la que tenga que exigirse el periodo de seguridad, arbitre un procedimiento clasificatorio de urgencia a fin de que el penado obtenga su clasificación en tercer grado si se dan los presupuestos legales en el menor tiempo posible". En efecto, dado que el periodo de seguridad es en su régimen general potestativo y dado los efectos negativos que puede tener el reingreso en prisión en caso de continuar pronóstico favorable de reinserción social, lo más conveniente sería dar traslado del expediente al JVP lo más pronto posible para que decida con carácter previo sobre el posible levantamiento del periodo de seguridad, pues se trata de personas que han logrado integrarse en la vida social normalizada tras un periodo obligatorio de encarcelamiento ${ }^{87}$.

\subsubsection{Regreso al Régimen general de cumplimiento:}

\section{la revocación del periodo de seguridad}

Para no incurrir en una contradicción absoluta con el principio de resocialización, el régimen general, además de ser potestativo, prevé puentes para volver al régimen general. Esta posibilidad existía ya antes de la reforma operada en 2010 cuando el instituto se mostraba imperativo y se mantiene tras esta reforma, si el periodo se blindó por parte del juez, siempre que no sea de obligado cumplimiento. Esta imposibilidad que en el texto original de 2003 alcanzaba únicamente a los delitos de terrorismo y aquellos otros come-

87 Propuesta SOLAR CALVO, M.P, “Consecuencias de la Ley orgánica...”, ob. cit., pág. 5. 
tidos en el seno de organizaciones criminales, ahora abarca un número más elevado de supuestos, por lo que, en sentido contrario a la flexibilización del sistema, lo convierte en rígido para un número mayor de delitos ${ }^{88}$.

La vuelta al régimen ordinario confiere nuevas atribuciones al JVP y al Juez sentenciador que resuelve los recursos contra sus decisiones, incrementándose, de este modo, la fiscalización judicial de la actividad administrativa en materia de clasificación de grado de tratamiento, en un proceso cargado de burocracia y no exento de contradicciones, que requiere lo siguiente:

a) El previo pronóstico individualizado y favorable de reinserción social exigido, es equivalente literalmente a lo que requería el art. 90. c) del Código Penal, en la redacción dada por la L.O. 7/2003, para el caso de la libertad condicional. En la actualidad, y tras la reforma llevada a cabo por LO 1/2015, para resolver sobre la suspensión de la ejecución del resto de la pena y la concesión de la libertad condicional el JVP valorará, además de la personalidad del penado, sus antecedentes, las circunstancias del delito cometido, los bienes jurídicos que podrían verse afectados por una reiteración en el delito, su conducta durante el cumplimiento de la pena sus circunstancias familiares y sociales, "los efectos que quepa esperar de la propia suspensión de la ejecución y del cumplimiento de las medidas impuestas", lo que, en principio, podría resultar equivalente porque en definitiva alude a un pronóstico de reinserción social. No obstante, tal vez no deba ser exigido en los mismos términos, pues aunque podría pensarse que en los dos casos es necesaria una valoración similar, debemos diferenciar nítidamente entre el régimen en semilibertad propio del tercer grado, y el estatus propio de la libertad condicional y siempre en aplicación del principio pro reo, pues en la práctica resulta una ardua labor evaluar conforme a los parámetros del art. 63 de la LOGP, a tenor de los cuales, la Administración Penitenciaria debe lidiar para la clasificación en grado, con conceptos jurídicos indeterminados como son la personalidad, el historial individual, familiar, social y delictivo, las facilidades o dificultades existentes y el momento adecuado para el buen éxito del tratamiento, entre otros factores. Todo ello a pesar de las sucesivas instrucciones de la DGIP, que tratan de objetivizar al máximo dichas circunstancias.

b) Acuerdo razonado del Juez de vigilancia penitenciaria, previo informe del Ministerio Fiscal, Instituciones Penitenciarias y las demás partes

Por "razonada" debemos entender motivada. En este sentido, el art. 120.3 de la CE es claro al exigir la motivación de todas las sentencias, exigencia que, según reiterada doctrina del $\mathrm{TC}^{89}$, forma parte del derecho a la tutela judicial efectiva consagrado en el

88 Así lo destaca BACH FABREGÓ, R. /GIMENO CUBERO, M.A., "Clases y contenido de penas y ejecución de las penas (arts. 33, 36, 39, 46, 50, 53, 56, 58, 66bis, 83, 100, 103 y $116 \mathrm{CP}$ )”, en QUINTERO OLIVARES, G., (Dir.), La reforma penal de 2010 , ob. cit., pág. 86 .

89 Vid., SSTC 143/1997, 83/1998 y 2/1999, entre otras, referidas a Autos del JVP. El Auto de la AP de Santa Cruz de Tenerife de 27 de julio de 2009 (La Ley 194597/2009) resuelve un recurso contra el Auto del JVP que acordaba no levantar el periodo de seguridad contando con el informe favorable de la Junta de Tratamiento y se desestima. El AAP de Madrid 706/2011 de 15 de febrero (La Ley 33544/2011) lo deniega por no concurrir los requisitos. El 
art. 24.1 del mismo texto. En efecto, el TC exige una cierta argumentación que permita saber "cuáles fueron los criterios jurídicos que fundamentaron la pretensión ejercitada", sin que baste "la mera aplicación a las personas implicadas de formularios preestablecidos sin la más mínima atención a las circunstancias del supuesto ni a las pretensiones en que se funda el recurso desestimado" Para esta vuelta al régimen general y el levantamiento del periodo de seguridad, el JVP debe, en consecuencia, realizar un pronóstico individualizado y favorable de reinserción social y valorar las circunstancias favorables del reo y la evolución del tratamiento reeducador mediante una resolución motivada que respete el derecho fundamental a la tutela judicial efectiva.

Para ello, previamente, la Junta de Tratamiento lo solicitará al juez de Vigilancia, valorando como criterios favorables la asunción del delito, la actitud de respeto a la víctima como compromiso de arrepentimiento, asunción o reparación del daño; la conducta en libertad entre la comisión del delito y el ingreso en prisión y la participación en programas específicos de tratamiento relacionados con la actividad delictiva ${ }^{90}$. No debe olvidarse, además que en los casos en los que se recurre la decisión del JVP de no levantar el periodo de seguridad para volver al régimen general de cumplimiento, no se recurre la obtención del tercer grado que deberá solicitarse, sino la posibilidad de obtenerlo y que no debe depender de requisitos más exigentes que la propia progresión al régimen de semilibertad, tal y como recuerdan algunas resoluciones con acierto ${ }^{91}$.

Por último el art. 36.2, inciso tercero CP exige la audiencia del "Ministerio Fiscal, Instituciones Penitenciarias y las demás partes".

No queda duda acerca de la necesidad de intervención del Ministerio Fiscal, pues según el art. 124.1 de la CE, éste tiene por fin "promover la acción de la justicia en defensa de la legalidad". Dicha posibilidad se desarrolla en el art. 4 del Estatuto Orgánico del Ministerio Fiscal que permite el examen de los expedientes de los internos y recabar cuanta información resulte conveniente. Dentro de esta facultad del Ministerio Fiscal, podemos incluir en otro orden de cosas, la obligación prevista en el art. $107 \mathrm{RP}$, de poner en conocimiento del mismo las resoluciones clasificatorias en tercer grado de tratamiento. Respecto a la nueva referencia a IIPP resulta innecesariamente reiterativa, por cuanto la audiencia a esta institución se producirá previamente a través de la emisión del pronóstico al que ya hemos hecho referencia con anterioridad.

La mención a "las demás partes" se ha de referir necesariamente, con una cláusula de estilo poco acertada, a la víctima del delito constituida en parte ${ }^{92}$, dando legitimidad procesal en fase de ejecución a las víctimas. Este apartado puede resultar discutible ${ }^{93}$

AAP de Madrid 2748/2009 (La Ley 198076) lo admite frente a resolución del JVP que lo deniega por no existir pronóstico individualizado favorable.

90 Criterios incorporados en las Instrucciones DGIP 9/2003 y 2/2004.

91 Vid., el AAP de Madrid 2748/2009 (La Ley 198076/2009), citado, frente al criterio del JVP.

92 Así, ACALE SÁNCHEZ, M., "Terrorismo..." ob. cit., pág. 348; RÍOS MARTÍN, J., "Reflexiones sobre la LO 7/2003...", ob. cit., pág. 108 y SOLAR CALVO "Consecuencias de la Ley Orgánica 7/2003 en el ámbito penitenciario”, Diario La Ley, 7238, D-279, 2009, pág. 1663 y ESPINA RAMOS, J.A, entendiendo que no puede referirse a las "demás partes" del ámbito penitenciario. "La reforma para el cumplimiento íntegro y efectivo de las penas: luces y sombras", ob. cit., págs. 25 y 26.

93 Así lo puso de manifiesto el ATC 373/1989, de 3 de julio (La Ley 2150/1989) avalando la exclusión de la legitimación de la acusación particular porque hay que distinguir la legitimación del Ministerio Fiscal, que ejercita el ius puniendi del Estado para la defensa de la legalidad y los intereses públicos, y la intervención del particular que "no ostenta derecho ni interés legítimo en el cumplimiento de la pena impuesta al reo". 
por cuanto si bien la víctima ha de tener su espacio en el sistema penal no resulta lo más adecuado este modo de implicación en la fase de ejecución ${ }^{94}$ salvo que se tratase de una fórmula de mediación o justicia restaurativa. El devenir del proceso penal con sus retrasos e imperfecciones suele generar el las víctimas un sentimiento de frustración y de falta de justicia que puede incrementar un ánimo vengativo poco recomendable en el trámite procesal de acceso al tercer grado, así como una victimización secundaria a volver a formar parte del procedimiento. Tampoco queda claro si se trata de una simple audiencia o un verdadero derecho de legitimación procesal. A ello ha de unírsele dificultades añadidas como la localización de estas u estas personas víctimas del delito, lo que viene a retrasar el procedimiento en cuestión.

El regreso al sistema general de cumplimiento resulta de este modo bastante complejo por la dificultad de llegar a un consenso entre todas las partes involucradas. Adviértase el periplo: para que el JVP deje sin efecto o anule el periodo se seguridad necesita un previo informe favorable de la Junta de Tratamiento que es quien solicita la vuelta al régimen ordinario ${ }^{95}$, por tanto, la iniciativa parte de Instituciones Penitenciarias ${ }^{96}$. Contando el JVP con dicho informe positivo, éste puede negarse al regreso al régimen ordinario fundamentándose en otros criterios objetivos, aun cuando se constate la evolución positiva del interno. Estos datos a tener en cuenta son: la asunción del delito ${ }^{97}$, la actitud respecto a la víctima, la conducta llevada a cabo en libertad durante el tiempo que media entre la comisión del delito y el ingreso en prisión, la participación en programas específicos de tratamiento y la evolución demostrada ${ }^{98}$ si bien el art. 36.2, inciso tercero CP, solo menciona como elementos valorables "las circunstancias personales del reo y la evolución del tratamiento reeducador". Recibida la aprobación judicial del levantamiento del periodo de seguridad en el Centro penitenciario, se remite el expediente completo con la propuesta de progresión a tercer grado a los Servicios Centrales para el visto bueno definitivo a nivel administrativo. Y si así fuera, esta resolución favorable se comunica nuevamente al JVP en cumplimiento de lo establecido en el art. 107 RP. Lo tortuoso y rocambolesco

94 Por el contrario, la LO 4/2015 de 27 de abril que regula el Estatuto de la víctima del delito, ha ampliado su intervención a la posibilidad de interponer recursos, que, en algunos supuestos, pueden afectar a la excarcelación del interno y a su programa de intervención, incluso aunque se trate de víctimas no personadas en el proceso. Críticamente, TAMARIT SUMALLA, J.M., "Los derechos de las víctimas" El Estatuto de las víctimas de delitos. Comentarios a la L. 4/2015, TAMARIT SUMALLA, J. M., Coord., Valencia, 2015, pág. 56. Entre sus derechos se encuentra el de recibir notificaciones de resoluciones judiciales o administrativas que afecten a sus intereses, como los permisos de salida o el tercer grado.

95 Vid. Instrucciones de la DGIP 2/2004 y 2/2005.

96 Planteando que ello supone, al tiempo, una desconfianza del legislador en el órgano jurisdiccional, LANDA GOROSTIZA, J. M., "Delitos de terrorismo y reformas penitenciarias (1996-2004): Un golpe de timón y correcciones de rumbo ¿hacia dónde?”, en CANCIO MELIÁ M. / GÓMEZ-JARA DÍEZ, C. (coords.), Derecho penal del enemigo: el discurso penal de la exclusión. Vol. II, Madrid, 2006, pág. 177.

97 Resoluciones de Audiencias Provinciales han matizado e incluso rectificado esta directriz que permitía fundar la decisión del JVP de no restablecer el régimen general de cumplimiento por la falta de asunción del delito cometido. Vid Sentencia AP de Cádiz 385/2008, de 2 de diciembre (JUR 2009/161384) o el AAP de Madrid 4735/2008, de 11 de diciembre (JUR 2009/88770) cuando afirma que "el esfuerzo por trabajar, por mejorar o incrementar la capacitación laboral representa asunción suficiente de la responsabilidad contraída, sin que la ejecución de la pena deba aspirar a provocar en quien se encuentra sometido a ella un arrepentimiento moral o conversión íntima puesto que la sentencia de condena penal tampoco contiene condena moral alguna, debiendo conformarse, como pertenece a las instituciones jurídicas, con la sumisión de la conducta externa a los valores del Derecho».

98 Vid. Instrucción DGIP 2/2005. 
del proceso establecido resulta patente, así como las altas cuotas de inseguridad Jurídica que presenta ${ }^{99}$ por la falta de taxatividad en los criterios que se tienen en consideración.

Pero más aún, en atención a la LO 4 /2015 de 27 de abril que regula el Estatuto de la Víctima del delito, estas pueden, además, impugnar resoluciones judiciales en sede de ejecución, siempre que hayan ejercido el derecho que el Estatuto les otorga de recibir notificaciones. Y, por lo que al tema que tratamos respecta, la víctima puede recurrir el Auto del JVP por el que se levanta el periodo de seguridad impuesto por el Tribunal sentenciador ${ }^{100}$ para que se pueda progresar al tercer grado sin haber cumplido la mitad de la condena ${ }^{101}$. Si tenemos en cuenta que la Junta de Tratamiento hace una propuesta de revocación al Juez de Vigilancia atendiendo a unos criterios (asunción del delito, actitud de respeto a la víctima, conducta en libertad antes de entrar en prisión y participación en programas de tratamiento) parece difícil que la víctima pueda fundar su pretensión en motivos que no sean puramente retributivos. De esta forma, la participación pasiva, limitada a darles audiencia, se ha transformado en una participación activa de poder recurrir e influir desde una posición subjetiva y parcial en decisiones que deben priorizar, por mandato constitucional y de la propia LOGP, la evolución del interno y su capacidad para adquirir cuotas de mayor libertad en aras a su reinserción social ${ }^{102}$.

La dificultad del proceso mismo y de entendimiento entre las partes participantes con la necesidad de conjugar sucesivamente las voluntades de los diferentes órganos administrativos y judiciales con el consiguiente aumento de burocracia, unido al perturbador papel que asume la víctima que puede impugnar el Auto del Juez de Vigilancia, queda patente en el dato constatable de que, en ocasiones, estando el interno sometido al periodo de seguridad, se opta por recurrir a lo previsto en el art. 100.2 $\mathrm{RP}^{103}$, el denominado segundo grado flexible ${ }^{104}$ que permite acudir a las actividades formativas en entidades colaboradoras durante las horas necesarias, siempre, previamente, con la aprobación del $\mathrm{JVP}^{105}$ lo que constituye un régimen de semilibertad muy similar al que proporciona el tercer grado con una no desdeñable economía procedimental. También puede utilizarse dicho recurso en caso de internos con una actividad laboral en el exterior.

99 Pueden ocurrir situaciones contradictorias que alargan el proceso. Así, si el JVP aprueba el levantamiento del periodo blindado a propuesta de la Junta de Tratamiento, pero se opongan los Servicios Centrales, debiendo recurrir en tal caso, nuevamente, al JVP.

100 También el Auto del Juez de Vigilancia por el que se acuerda la vuelta al régimen general de cumplimiento que anule lo dispuesto en el art. $78 \mathrm{CP}$ respecto al cálculo de beneficios penitenciarios, permisos de salida, tercer grado y libertad condicional sobre la totalidad de la condena y el Auto del Juez de Vigilancia que concede la Libertad condicional. Sobre el discutible protagonismo de la víctima en el cumplimiento de la pena de prisión, desconocido, por lo demás, en Derecho comparado por su capacidad de afectar aspectos tratamentales, RENART GARCÍA, F., "Del olvido a la sacralización. La intervención de la víctima en la fase de ejecución de la pena". Revista Electrónica de Ciencia Penal y Criminología, 17-14 (2015), pág. 6.

101 Eso sí, sólo en estos supuestos, no en aquellos de progreso general a tercer grado que es siempre competencia de la Administración penitenciaria y, por tanto, sólo recurrible por el Ministerio Fiscal.

102 Por ello, resultan más aconsejables las medidas dirigidas a su información como base de una adecuada protección con las medidas que sea necesario adoptar y la reparación del daño como instrumento válido para reducir la victimización. Así, CERVELLO DONDERIS, V., Libertad condicional..., ob. cit., pág. 60.

103 Así, SOLAR CALVO, M.P., “Consecuencias de la Ley Orgánica 7/2003...”, ob. cit., pág. 4.

104 Vid., sobre el mismo, la Instrucción DGIP 9/2007.

105 GARCÍA ALBERO, R. en GARCÍA ALBERO R. / TAMARIT SUMALLA, J.M., advierte, no obstante, sobre este modelo contemplado en el art. 100.2 RP, sobre «su escasa aplicación práctica y el carácter excepcional de dicha medida", La reforma de la ejecución penal, 2004, pág. 40. 


\subsection{Régimen agravado de art. $36.2 \mathrm{CP}$, tercer inciso: el periodo de seguridad obligatorio y no revocable}

La LO 5/2010 precisa los supuestos en los que el "juez o el tribunal" está obligado a establecer un periodo de seguridad: aquellos casos en que la pena de prisión impuesta sea grave años correspondiendo, además, a alguno de los delitos que se enumeran en el art. 36.2 CP tercer inciso ${ }^{106}$. Ciertamente, esta enumeración consigue limitar notablemente el grupo de delitos para lo que resulta obligatorio este periodo blindado de cumplimiento de la pena de prisión en el centro penitenciario e, incluso, en el marco de los delitos enumerados, la pena debe ser, igualmente, superior a cinco años. Sin embargo, como se viene exponiendo, la imposibilidad de regresar al régimen general y progresar de grado mientras no se superen unos parámetros temporales y, por tanto, objetivos no franqueables, choca frontalmente con el sistema de individualización científica proclamado en la LOGP suponiendo, al tiempo, diversos problemas de compatibilidad con el texto constitucional, no sólo por no tener en cuenta la evolución del tratamiento que posibilitara la vuelta al régimen general, sino por la posible vulneración del principio de igualdad.

En efecto, se ha llegado a argumentar que esta excepción para este tipo de delincuencia puede dar lugar a problemas de constitucionalidad ya que, a diferencia de los demás supuestos, excluye a priori y de forma absoluta cualquier tipo de evolución favorable de este tipo de internos, incluso en el caso de rechazo expreso de las actividades terroristas ${ }^{107}$. En este sentido, la pregunta apunta a si dicha exclusión de determinados delincuentes o personas que han cometido un cierto tipo delictual puede vulnerar el principio de igualdad consagrado en el art. $14 \mathrm{CE}$, pues la expresión "no podrá efectuarse" deja claro la obligatoriedad del cumplimiento de la mitad de la pena (antes de la reforma de 2010 decía cuando no se trate de delitos de delitos de terrorismo o cometidos en el seno de organizaciones criminales).

Evidentemente, se puede esgrimir que nuestro Texto constitucional no sólo recoge el principio de igualdad formal en su art. 14 sino que contempla la llamada igualdad material que se exterioriza en el derecho del ciudadano a no sufrir discriminación jurídica alguna, esto es, a no ser tratado diferente sin que exista justificación objetiva alguna, por cuanto en igualdad de condiciones, el trato ha de ser igualitario, pero puede serlo si existe un elemento diferencial. Pero lo cierto es que habría que volver a plantear las cuestiones de eficacia de semejante medida en orden a la motivación, por ejemplo, de un terrorista para colaborar con las autoridades si ello no le va a reportar alguna ventaja en orden a la progresión de grado y solo se podrá tener en cuenta cuando haya transcurrido la mitad de la condena, o incluso, de la suma de las penas, en muchos casos de muy larga duración ${ }^{108}$.

106 «a) Delitos referentes a organizaciones y grupos terroristas y delitos de terrorismo del Capítulo VII del Título XXII del Libro II de este Código.

b) Delitos cometidos en el seno de una organización o grupo criminal.

c) Delitos del art. $183 \mathrm{CP}$.

d) Delitos del Capítulo V del Título VIII del Libro II de este Código, cuando la víctima sea menor de trece años.»

107 ESPINA RAMOS, J. A., "La reforma para el cumplimiento íntegro y efectivo de las penas...”, ob. cit., pág. 27.

108 Como indica LLOBET ANGLI, M., el periodo de seguridad tendrá un efecto contrario al interés de la colaboración si el premio de la ayuda es obtener el tercer grado muchos años después Y, al tiempo, ¿cuál será la importancia y eficacia de la información veinte años después de su ingreso en prisión? "La ficticia realidad modificada por la Ley de Cumplimiento íntegro y efectivo de las penas y sus perversas consecuencias” InDret, 2007, pág.15 
La falta de incentivos para la persona que cumple pena de prisión, resulta evidente ${ }^{109}$ y las finalidades retributivas de parte de la misma, también.

\subsection{Régimen excepcional}

Con anterioridad a la reforma operada por LO 1/2015 y a consecuencia de la falta de previsión expresa acerca de un régimen excepcional para enfermos incurables y septuagenarios, se producía una disfuncionalidad respecto a lo establecido en el art. 104. 4 $\mathrm{RP}^{110}$ que prevé la posibilidad de evolución al tercer grado por razones humanitarias $\mathrm{y}$ de dignidad personal de estos penados, atendiendo a la dificultad para delinquir y a su escasa peligrosidad. Por tal razón, se debe valorar positivamente que la Reforma operada por LO 1/2015 modificara el art. 36.2 CP para incluir un apartado tercero que contemplase expresamente, tal como hace en la actualidad, que el periodo de seguridad no vendrá en aplicación cuando se trate de enfermos muy graves con padecimientos incurables o de los septuagenarios "valorando pericialmente su escasa peligrosidad"111. Pese a lo acertado de esta mención, no puede dejar de ponerse de relieve que esta situación ya se venía produciendo de facto para no dejar inoperativo y vacío de contenido el art. $92 \mathrm{CP}$ que en su redacción anterior a la reforma de 2015 permitía a los recursos en esas situaciones obtener la concesión de la libertad condicional sin presentar los requisitos temporales de cumplimiento mínimo exigidos en el régimen general o especial, aunque sí el resto de los mencionados en el art. 90.1 CP entre los que figuraba, en primer término, encontrarse "en el tercer grado de tratamiento penitenciario". Esta descoordinación entre preceptos, dado que el art. $36 \mathrm{CP}$ nada refería al respecto, podía dar lugar, si no se realizaba una interpretación a favor del reo, a que no se concediera la libertad condicional por no haber cumplido el periodo preceptivo para acceder al tercer grado, sin que la situación fuera modificable, de algún modo. Ante este escenario, aunque los supuestos venían encontrando solución en la práctica, se hacía necesaria una sintonización del nuevo art. 36.2 CP y la normativa penitenciaria (art. 104.4 RP) $)^{112}$ que recoge este mismo supuesto pero exigiendo adicionalmente, informe médico ${ }^{113}$ y a tribuyendo al Centro

109 Considerando que, incluso podría ser una forma de ejecución inhumana MUÑAGORRI LAGUIA, I., en "Derecho penal intercultural y crisis del principio de soberanía..." ob. cit., pág. 189, y catalogando el sistema como "una forma de pena de muerte de ejecución lenta".

110 La Instrucción 9/2003 de DGIP parecía dejar zanjada la cuestión al prever que en tanto que el art. 92 CP les sigue eximiendo de los requisitos temporales para la libertad condicional, por el mismo motivo se les ha de eximir de los requisitos temporales para el tercer grado. Criterios reiterados por las Instrucciones 2/2004 y 2/2005 del mismo Instituto. No obstante, ello podía comprometer el principio de legalidad. En tal sentido, CERVELLÓ DONDERIS, V., al no estar previsto tal régimen en el art. 36.2 CP, "Los nuevos criterios...", ob. cit. 2004, pág. 13. El AAP de Madrid 174/2008, de 16 de enero (JUR 2008/99386) consideró no afectado el art. 104.4 RP por el periodo de seguridad.

111 La redacción difiere algo de la inicialmente proyectada, ya que en el Anteproyecto se habían olvidado de estas condiciones de excepcionalidad en atención de las circunstancias personales del penado cuando se tratase de septuagenarios que, finalmente, fueron incorporadas en el Proyecto. Se elimina, al tiempo, la expresión referida a "la dificultad para delinquir" por resultar poco adecuada y reiterativa, si bien sea la utilizada por la normativa penitenciaria.

112 "Los penados, enfermos muy graves con padecimientos incurables, según informe médico, con independencia de las variables intervinientes en el proceso de clasificación, podrán ser clasificados en tercer grado por razones humanitarias y de dignidad personal, atendiendo a la dificultad para delinquir y a su escasa peligrosidad".

113 Ya la Instrucción DGIP 2/2005 de 15 de marzo consideró innecesario cumplir en estos casos el periodo de seguridad por cuanto el art. $92 \mathrm{CP}$ (en su redacción vigente que vendría a corresponderse con el actual 91.1 CP) exime de los requisitos temporales en el mismo supuesto para la libertad condicional. 
directivo la competencia ${ }^{114}$. En el caso que nos ocupa, la competencia será, como indica el inciso tercero del art. 36.2 "según corresponda" del Tribunal sentenciador - aunque no lo diga expresamente, se refiere a penados a prisión permanente revisable- o del Juez de Vigilancia Penitenciaria, tratándose de la prisión temporal.

Por otra parte, dada la ubicación de esta salvedad que contempla, en suma, un régimen excepcional inmediatamente después de los apartados dedicados a la prisión permanente revisable (art. 36.1 CP) y a la prisión ordinaria (art. 36.2 CP) y sus correspondientes periodos de seguridad, así como por la expresa referencia a las distintas competencias según proceda para tomar el acuerdo, habrá que considerar, puesto que además se señala "en todo caso" que esta regla excepcional del párrafo tercero alcanza a los dos números anteriores y, en consecuencia, a los dos tipos de prisión: la temporal y la indefinida ${ }^{115}$. No obstante, debería haberse previsto expresamente, por los mismos motivos de dignidad y humanidad, una regla semejante para las hipótesis concursales reguladas en el art. 78 bis CP que establece plazos distintos y mucho más elevados para la progresión al tercer grado si uno de los delitos perpetrados estuviese castigado con PPR. Queda por ver cómo se resolverán estas situaciones en el futuro.

También alcanza, por los mismos motivos humanitarios y porque se indica "en todo caso" a aquellos penados que hayan cometido alguno de los delitos que implican el régimen agravado sin posibilidad de levantamiento del periodo de seguridad, al tratarse de un supuesto excepcional y de carácter universal.

\section{REQUISITOS ADICIONALES PARA LA OBTENCIÓN DEL TERCER GRADO}

\subsection{Satisfacción de la Responsabilidad civil}

La LO 7/2003 introduce, al tiempo, dos nuevos apartados en el art. 72 LOGP. En el primero de ellos (art. 72.5) se establece que la clasificación inicial o progresión al tercer grado penitenciario requerirá, además de los requisitos recogidos en el $\mathrm{CP}$, que el penado haya satisfecho la responsabilidad civil derivada del delito"16. "Singularmente" advierte - sin que la expresión resulte aclaratoria, si está referida a en todo caso o si especialmente o exclusivamente- se aplicará esta norma cuando la condena devenga de la comisión de delitos contra el patrimonio o el orden socioeconómico, cuando concurran las circunstancias agravantes de notoria gravedad y perjuicio a una generalidad de personas; delitos contra los derechos de los trabajadores; contra la Hacienda Pública y la Seguridad Social;

114 Vid. Instrucción DGIP 6/ 2018 sobre el procedimiento para la emisión de informe médico y tramitación de la suspensión de la ejecución de la pena privativa de libertad por enfermedad muy grave con padecimientos incurables.

115 Así lo defendí en su día en MORILlAS CUEVA, L., (Dir.) "El nuevo sistema de penas a la luz de las últimas reformas". Estudios sobre el Código penal Reformado (Leyes Orgánicas 172015 y 2/2015, Madrid, 2015, pág.159. Igualmente, considerando que la excepción alcanza también a la PPR, vid. el Informe del Consejo de Estado: Dictamen al Anteproyecto de Ley Orgánica por la que se modifica la LO 10/1995 de 23 de noviembre, del Código penal, 358/2013, séptimo (B).

116 Aplaudiendo la medida, ESPINA RAMOS, J.A, "La reforma para el cumplimiento íntegro y efectivo de las penas: luces y sombras”, ob. cit., págs. 31. 
y los cometidos contra la Administración Pública comprendidos en los Capítulos V al IX del Título XIX del Libro II. Respecto a la precisión que realiza el precepto, la instrucción DGIP 2/ 2005 establece que "singularmente" no significa que se trate de un régimen diferente para estos delitos a la hora de analizar la concurrencia del requisito de la responsabilidad civil, sino que simplemente se exige su valoración de forma más destacada, lo que, sin duda, no resulta muy aclaratorio ${ }^{117}$ aunque, al menos, deja claro que afecta a todos los delitos.

Lo que, en principio, pudiera considerarse como un requisito legal de fácil comprobación, la redacción del precepto y su valoración, así como las dificultades que origina su puesta en práctica nos llevan a un panorama diferente y más complejo, a pesar de que la EM de la Ley que introduce este requisito considera que viene a introducir "mayor certeza acerca del pronóstico favorable de reinserción de los internos que acceden al tercer grado (Apartado VIII) ${ }^{118 "}$. No obstante, los parámetros que se introducen a reglón seguido para valorar este requisito resultan de todo menos taxativos. Así, se considerará a tales efectos "la conducta efectivamente observada en orden a restituir lo sustraído, reparar el daño e indemnizar los perjuicios materiales y morales; las condiciones personales y patrimoniales del culpable, a efectos de valorar su capacidad real, presente y futura para satisfacer la responsabilidad civil que le correspondiera; las garantías que permitan asegurar la satisfacción futura; la estimación que del enriquecimiento que el culpable hubiera obtenido por la comisión del delito $\mathrm{y}$, en su caso, el daño o entorpecimiento producido al servicio público, así como los daños y perjuicios causados por el delito, el número de perjudicados y su condición". Tal cantidad de criterios hubiera merecido una aclaración en el Reglamento que determinara de forma más concreta los términos de la Ley. Como ello no se hizo aprovechando la misma reforma, han sido las Instrucciones de la DGIP las que se fueron pronunciando en una evolución que contempla desde una interpretación más restrictiva cifrada en la Instrucción 9/2003, exigiendo, al menos, abonos parciales de la citada responsabilidad civil para poder acceder al tercer grado ${ }^{119}$, llegando a la Instrucción 2/2004 que se muestra más favorable a flexibilizar el requisito, atendiendo a la capacidad económica de la población penitenciaria y, en consecuencia, permitiendo la progresión de grado si media el compromiso del interno de abono futuro de la responsabilidad civil, siendo las Juntas de Tratamiento las que llevaran a cabo la labor de valorar la presencia del requisito, y, finalmente, la Instrucción 2/2005 que insiste en que debe valorarse el requisito conforme a un doble criterio: uno objetivo referido a los casos en los que la responsabilidad civil ha sido abonada o la víctima ha renunciado a ella, en cuyo caso queda claro ${ }^{120}$, y en segundo término, el criterio subjetivo que incide en la voluntad

117 Como señala LLORET ANGLÍ, M., "La ficticia realidad modificada...”, ob. cit., pág. 12, llama la atención por incongruente respecto al art. 72.6 LOGP que no se incluyan los delitos contra las personas, produciéndose una distinta valoración de las víctimas.

118 El Informe del CGPJ al Anteproyecto de lo que sería la LO7/2003, hacía notar que no se puede aplicar este requisito de forma estricta porque ello supondría hacer depender los márgenes de libertad personal de una contingencia económica, (pág. 27), abogando por una interpretación en la que se tome en consideración, no ya la satisfacción real de la responsabilidad civil, sino el esfuerzo empleado por el condenado para dar contenido al informe pronóstico de comportamiento futuro.

119 Proponiendo, al tiempo, que fueran los JVP los que valoraran finalmente la satisfacción o no de dicho requisito antes de la propuesta administrativa de tercer grado. Postura ya mantenida por RÍOS MARTÍN, J., "Reflexiones...", ob. cit., pág. 115 .

120 En el caso de los internos insolventes parece que este documento los incluye dentro de los supuestos en los que prima el criterio objetivo. Sin embargo los vuelve a mencionar al tratar el criterio subjetivo, cuando se refiere a 
y capacidad de pago por parte del interno" aunque sin mayor especificación, por lo que no ayuda demasiado a la interpretación del precepto y dependiendo en suma de la valoración discrecional que realice la Junta de Tratamiento ${ }^{121}$. En este sentido, la seguridad jurídica no se tomado suficientemente en consideración.

En cuanto a la posibilidad de que afecte al principio general establecido en el art. 72.4 LOGP referido a la prohibición de mantener a un interno en un grado inferior al que corresponda por su evolución, se puede considerar que esta regulación supone una excepción legal a dicho principio, en cuanto establece una especial regulación para un supuesto específico y que además resultaría raro que se produjese una contradicción entre ambos apartados del art. 72 LOGP toda vez que difícilmente podrá sostenerse que hay una adecuada evolución de un interno que, pudiendo hacerlo se niegue a satisfacer las responsabilidades civiles por lo que ello implica de ausencia de interiorización de las obligaciones derivadas de una vida normalizada en la sociedad. Pero lo cierto es que la contradicción en los términos existe y hace que el requisito se convierta en un elemento obstativo para la progresión en el tratamiento. Por ello ha de interpretarse con sumo cuidado para no contravenir aquel principio rector.

La interpretación y forma de aplicación del requisito en cuestión en el caso de enfermos muy graves con padecimientos incurables, resulta más clara porque prevalecen los criterios de dignidad y razones humanitarias sobre el interés de la víctima. En el caso de los septuagenarios, el criterio subjetivo para determinar el abono exigible se ha aplicado con mucha más flexibilidad, atendiendo, sobre todo su escasa capacidad para mejorar en su capacidad económica. En el caso de remisión a una comunidad terapéutica (art. 182 RP) sí suele exigirse un compromiso de cumplimiento y pago de la responsabilidad civil, aun cuando la efectividad pueda demorarse hasta la conclusión del tratamiento ${ }^{122}$.

Finalmente, serían los Juzgados y Tribunales sentenciadores, los mejor dotados para asegurar la persecución, valoración y actualización del patrimonio de los condenados para así lograr la satisfacción real de las víctimas y/o perjudicados. El hecho de que se canalice a través de los Centros penitenciarios origina una duplicidad administrativa, que termina por crear un procedimiento caótico e ineficaz. Piénsese que la Administración penitenciaria no cuenta con los recursos necesarios para lograr determinar la verdadera capacidad económica de cada interno. Por ello, finalmente, el abono a través de cantidades parciales de muy poca entidad supone una especie de pacto semificticio para poder acceder al tercer grado con independencia de la satisfacción de la responsabilidad civil

La redacción del precepto permite, no obstante, que sean los Jueces de Vigilancia quienes valoren las circunstancias concurrentes en cada caso, atendiendo a las cantidades satisfechas y las condiciones personales y patrimoniales del culpable para evitar que se produzcan estos fraudes por la vía de pagar cantidades insignificantes de dinero con la

la capacidad y voluntad de abono del interno incluso en casos de insolvencia. Con ello parece que no quedan del todo exentos del requisito a efectos de obtener el tercer grado. No obstante hay que contar con que la declaración de insolvencia de los internos no siempre se corresponde con la realidad, por ello se ha defendido la legitimidad de exigir pagos parciales según el peculio de cada uno. Así, LÓPEZ CERRADA, V.M., "La responsabilidad civil en la LO 7/2003 y su incidencia en el tratamiento penitenciario". Revista de Estudios Penitenciarios, n 252, 2006, pág. 23.

121 Tampoco queda claro si el art. 607 LEC resulta de aplicación a los efectos de las cuantías de sueldo y salario inembargables en estos supuestos.

122 Vid. LÓPEZ CERRADA, V. M. “La responsabilidad civil en la LO 7/2003...”, ob. cit., pág. 31. 
única finalidad de acceder a los beneficios penitenciarios. El hecho de que toda cantidad satisfecha, por pequeña que sea deba ser tenida en cuenta por el tribunal sentenciador en su ejecutoria, no ha de significar de forma automática que el Juzgado de Vigilancia considere cumplido ipso facto este requisito.

Pero independientemente de todas las matizaciones realizadas y la atención a la conducta realmente observada, lo cierto es que nos encontramos a partir del momento en que se incorpora el requisito con que el cumplimiento de una obligación civil pasa también a condicionar el proceso de reinserción social del condenado.

\subsection{Abandono de los fines y medios terroristas}

Son varias las disposiciones que desde 2003 relacionan directamente la progresión en la resocialización con una petición expresa de perdón a las víctimas. En esta línea se enmarca el apartado 6 del art. 72 LOGP que, siendo el segundo de los apartados introducidos por la LO 7/2003 y requisito imprescindible también para el informe favorable que precede a la libertad condicional, establece la necesidad de, además de observar los requisitos del apartado anterior y para los casos de delitos terroristas o cometidos en el seno de organizaciones criminales, que el penado muestre signos inequívocos de haber abandonado los fines y los medios terroristas y haya colaborado activamente con las autoridades bien para impedir la producción de otros delitos por parte de la banda armada, organización o grupo terrorista, bien para atenuar los efectos de su delito, bien para la identificación, captura y procesamiento de los responsables de delitos terroristas, para obtener pruebas o para impedir la actuación o el desarrollo de las organizaciones o asociaciones a las que haya pertenecido o con las que haya colaborado ${ }^{123}$.

Este requisito, integrador de muchos, para el acceso al tercer grado y el previsto paralelamente para la libertad condicional ${ }^{124}$ se aplica además retroactivamente, confor-

123 En esta línea, los arts. 90 y 92 CP, permiten, que no obligan, que el requisito de "haber abandonado los fines y los medios de la actividad terrorista y haber colaborado activamente con las autoridades" -que ya de por sí iría más allá de lo que exige la resocialización-, se acredite mediante "una declaración expresa de repudio de sus actividades delictivas y de abandono de la violencia y una petición expresa de perdón a las víctimas de su delito, así como por los informes técnicos que acrediten que el preso está realmente desvinculado de la organización terrorista y del entorno y actividades de asociaciones y colectivos ilegales que la rodean y su colaboración con las autoridades".

$124 \mathrm{La}$ inclusión de estos nuevos requisitos de acceso a tercer grado y a la libertad condicional operada por la LO 7/2003 resulta criticable por muchas cuestiones pero, fundamentalmente, porque se le obliga al sujeto no sólo a renunciar a los métodos sino también a los fines a o a sus ideas, adentrándose en la ética del sujeto, la exigencia de delación o la quiebra del principio de igualdad al establecer un régimen excepcional con la única finalidad de lograr el cumplimiento íntegro en prisión de las condenas recaídas por terrorismo, con olvido absoluto de la finalidad resocializadora Vid, entre otros, ACALE SÁNCHEZ, M., "Terrorismo, delincuencia organizada y sistema de penas" en FARALDO CABANA, P./PUENTE ALBA, L. M./BRANDARIZ GARCÍA, A. (Coord.), Nuevos retos del Derecho penal en la era de la globalización, Valencia, 2004, págs. 341 y ss..; FARALDO CABANA, P., "Medidas premiales durante la ejecución de condenas por delitos de terrorismo y delincuencia organizada: consolidación de un subsistema penal y penitenciario de excepción", en CANCIO MELIÁ M., GÓMEZ-JARA DÍEZ C. (Coord.), Derecho penal del enemigo. El discurso penal de la exclusión. Vol. 1, Madrid, 2006, págs. 771 y ss.; la misma autora, "Un derecho penal de enemigos para integrantes de organizaciones criminales. La Ley Orgánica 7/2003, de 30 de junio, de medidas de reforma para el cumplimiento íntegro y efectivo de las penas". Nuevos retos..., ob. cit. págs. 317 y ss.; DUFRAIX TAPIA. R. A., "Algunas reflexiones sobre la petición de perdón a las víctimas de delitos terroristas en España”, en Eguzkilore, núm. 22, 2008, pp. 117 y ss.; RENART GARCÍA F., La libertad condicional. Nuevo régimen jurídico: adaptada a la L.O. 7/2003, de 30 de junio, de medidas de reforma para el cumplimiento íntegro y efectivo de las penas, Madrid, 2003, pág. 189; RODRÍGUEZ YAGÜE, A. C., "El modelo penitenciario español frente al terrorismo" en La ley penal, Revista de Derecho Penal, Procesal y Penitenciario, $\mathrm{N}^{\circ} .65,2009$, pág. 74 y ss. y CANO PAÑOS, M. A., "El régimen penitenciario de los terroristas 
me a su Disposición transitoria única (DTU) de la LO 7/2003, en una aplicación hacia el pasado dudosamente compatible con el principio de legalidad aunque avalada por el CGPJ al afirmar que se trata de un supuesto de "retrospección" o "retroactividad impropia", por incidir sobre una situación o relación jurídica actual aún no concluida ${ }^{125}$ Todo ello, a pesar de que el propio TS ha considerado que la aplicación retroactiva de un régimen de ejecución más severo queda vedada por el principio de irretroactividad de la ley penal desfavorable, al admitir, por lo mismo, el recurso de casación contra la aplicación retroactiva del art. 36 del Código penal ${ }^{126}$.

\section{a) Muestra de signos inequívocos de haber abandonado los fines y medios de la actividad terrorista}

Este requisito puede acreditarse con una declaración expresa de repudio de sus actividades delictivas y abandono de la violencia y la petición expresa de perdón a las víctimas de su delito ${ }^{127}$ o con informes técnicos que acrediten la desvinculación del preso de la organización terrorista y del entorno y actividades de asociaciones y colectivos ilegales que la rodean ${ }^{128}$ y su colaboración con las autoridades.

Bajo el convencimiento de la inexistencia de una aplicación retroactiva de la ley desfavorable y bajo el manto de la citada DTU de la LO 7/2003, así como con el argumento de que ello podría extraerse por vía interpretativa de lo establecido por la ley con anterioridad a la reforma de 2003 por cuanto es algo que conecta con la resocialización del penado, el requisito al que aludimos se ha extendido incluso a las decisiones de pasar de primer a segundo grado con la relevancia práctica que ello comporta si se tiene en consideración que los condenados por terrorismo son cuasi automáticamente clasificados en primer grado por aplicación del art. $192.5 \mathrm{RP}^{129}$ al considerarse una situación de "peli-

de ETA: ¿Mantenimiento, supresión o modificación?’. Diario La Ley, núm. 7821, Sección Tribuna, Año XXXIII, 20 Marzo de 2012, págs. 4 y ss. Considerando la disposición coherente con la filosofía de la Reforma, y con una adecuada concepción de la naturaleza y finalidad de la clasificación penitenciaria, ESPINA RAMOS, J.M., "La reforma...", ob. cit., pág.34, aduciendo que si sus ideas le impiden dar este paso, es evidente que su tratamiento no ha dado el fruto deseado.

125 Vid. Informes del Consejo General del Poder Judicial sobre las Reformas penales, Centro de Documentación Judicial, Madrid, 2003, pp. 50-51. y la STC 42/1986, de 10 de abril, a favor de distinguir entre retroactividad auténtica y retroactividad impropia diferenciando para ello entre efectos jurídicos ya consolidados y meras expectativas. En contra se pronunciaba gran parte de la doctrina. Así, RODRÍGUEZ YAGÜE, A. C., "El modelo penitenciario español frente al terrorismo" en La ley penal: revista de Derecho Penal, Procesal y Penitenciario, núm. 65, 2009, pág. 78; LANDA GOROSTIZA, J. M., "Delitos de terrorismo y reformas penitenciarias (19962004): Un golpe de timón y correcciones de rumbo ¿hacia dónde?”, en CANCIO MELIÁ M., GÓMEZ-JARA DÍEZ C. (Coords.), Derecho penal del enemigo. El discurso ..., ob. cit., pág. 182; JUANATEY DORADO, C., "La Ley de Medidas de Reforma para el cumplimiento íntegro y efectivo de las penas, y los principios constitucionales del Derecho Penal". La ley penal. Revista de Derecho penal, procesal y penitenciario, núm. 9, 2004, págs. 5 y ss. e IGLESIAS RÍO, M. A., "Algunas reflexiones sobre retro-irretroactividad de la ley Penal. A propósito de las últimas reformas del Código penal”, Revista Jurídica de Castilla y León, núm. 6. Mayo, 2005, pág. 33.

126 Vid. STS 748/2006 de 12 de junio.

127 Para lo que haría falta una labor de mediación con programas adecuados.

$128 \mathrm{La}$ acreditación de esta desvinculación por parte del centro penitenciario resulta compleja por lo limitado de sus medios y porque el distanciamiento físico o el control de las comunicaciones y visitas puede derivar en un aislamiento carcelario que origine problemas adicionales

129 Vid. Auto JCVP de 4 de noviembre de 2019 manteniendo el primer grado del interno por la trayectoria delictiva, de los delitos especialmente graves cometidos no dar ninguna muestra de pedir perdón a las víctimas del delito, ni de satisfacer la responsabilidad civil, dado el tiempo de cumplimiento de condena, que no llega a la mitad de la misma y en contra del informe de la Junta de Tratamiento. 
grosidad extrema"130. El cumplimiento de este requisito no resulta tan fácil en la práctica. De hecho, la AN se muestra en ocasiones especialmente estricta, rechazando misivas que no contengan la palabra expresa "perdón" dirigida a las víctimas o sus familiares ${ }^{131}$ o aduciendo - ¿se extraña?- el carácter finalista de los escritos o la identidad con otros presentados por otros reclusos ${ }^{132}$. Hay que recordar, no obstante, que la ley establece que el abandono de los fines y los medios terroristas puede acreditarse mediante la declaración expresa de repudio con petición de perdón o (por tanto, alternativamente) mediante los informes técnicos, por lo que no se justifican las resoluciones en las que la Audiencia Nacional ha rechazado tanto la una como los otros, para afirmar que sin arrepentimiento y solicitud de perdón expreso a las víctimas concretas no había evolución en la resocialización que justificara la progresión en grado ${ }^{133}$.

La discusión sobre el contenido que pueda tener el mandato constitucional (art. 25.2) de orientar las penas privativas de libertad a la reeducación y reinserción social del penado, conecta con el debate acerca de la legitimidad del Estado para intervenir de forma coactiva y utilitaria sobre la ética personal del condenado ${ }^{134}$. A este respecto, el derecho fundamental al libre desarrollo de la personalidad, también de rango constitucional, impediría una intervención de tipo ideológico o de adoctrinamiento en determinados valores. Sólo hay que contemplar lo que prescribe el art. 59.1 LOGP poniendo de relieve que el tratamiento pretende hacer del interno "una persona con la intención y la capacidad de vivir respetando la ley penal, así como de subvenir a sus necesidades. A tal fin se procurará, en la medida de lo posible, desarrollar en ellos una actitud de respeto a sí mismos y de responsabilidad individual y social (...)"135.

En este sentido, si partimos de la creencia de que la pena sí puede realmente cumplir una función de prevención especial positiva ${ }^{136}$, debemos hacer hincapié en que el tratamiento resocializador -voluntario, por cierto,- y la finalidad de la pena no es intervenir ni moldear la ética del sujeto, sino que se conforma con la adecuación del comportamiento personal a lo establecido por las normas vigentes. Por esta razón se ha destacado, con acierto, que carece de legitimidad diseñar un régimen de ejecución más severo o negarle al condenado los beneficios o la progresión que merecería conforme a los requisitos ge-

130 No obstante, como advierte GIL GIL, A., son infrecuentes las solicitudes de beneficios penitenciarios o de progresión de grado con anterioridad a 2014 porque la organización terrorista ETA prohibía hasta 2013 acogerse a la legislación penitenciaria. "El requisito de "petición expresa de perdón a las víctimas". ¿signo de la progresión personal en el proceso de resocialización?" RGDP, núm. 35, 2021, págs. 6 y ss.

131 Vid., AAN 321/2018, secc. $1^{\text {a }}$ de 12 de abril, en un caso de redenciones extraordinarias.

132 Vid., AAN 943/2020 y 944/2020, ambos de 30 de diciembre.

133 AAN 943/2020, de 30 de diciembre de 2020.

134 LANDA GOROSTIZA, J. M., ha tildado esta medida de "exigencia de retractación ideológico-social, respecto de la cual subyace, tácitamente, la identificación de cualquier empatía con el tejido sociopolítico cercano al terrorismo como factor criminógeno de primer grado", una "especie de "criminalidad ideológica". "Delitos de terrorismo y reforma..., ob. cit., pág. 198. Críticamente, también, con el requisito de colaboración activa con las autoridades mediante un informe técnico por cuanto "un sujeto puede estar resocializado y no querer por diversas razones (miedo, motivos ideológicos, etc.) colaborar con la justicia (que no es lo mismo que querer seguir cometiendo delitos terroristas), considerando que podía considerarse positivo en la evaluación del interno pero no establecer su carácter obligatorio.

135 Vid. también, art. 60 LOGPJ y 110 RP y la Instrucción 18/2019 sobre "La actualización de la Instrucción sobre la aplicación del art. 86.4 del RP” que regula los medios de control telemáticos y los centros del Inserción Social.

136 Expresando sus dudas, CERVELLÓ DONDERIS, V., "El sentido actual del principio constitucional de reeducación y reinserción social", en VVAA, Presente y futuro de la Constitución española de 1978, Valencia, 2005, págs. 217 y ss. 
nerales si con ello se pretende forzar una modificación de sus convicciones ${ }^{137}$. Aunque se argumente buscando datos objetivos que se alejen del concepto de expiación, que los tribunales, al comprobar la evolución del sujeto consideran que quien no asume el daño causado o no muestra arrepentimiento por el delito cometido, presenta un mayor riesgo de reiteración delictiva, lo cierto es que la Jurisprudencia muestra que no se conforma con que el sujeto acepte la vigencia de la norma, exigiendo un arrepentimiento moral y una petición de perdón como fin en sí mismo que sustituye el análisis sobre el pronóstico individualizado de reincidencia e incluso cuando se compruebe que no exista tal riesgo.

Por otra parte, esta visión moralista hacia las víctimas del requisito legal, sitúa al operador jurídico en la disyuntiva de tener que comprobar la veracidad de un arrepentimiento-perdón cuya sinceridad no sólo se muestra incomprobable, sino que al ser finalista o utilitario es lógico que sea interesado, pues así se ha diseñado por la propia Ley. Por tanto, nada aporta esta puesta en escena al proceso de resocialización, al menos como requisito indispensable, en este caso para progresar de grado. Si puede ser considerado y alcanzar cierta relevancia (en positivo no como elemento obstativo) en todos los delitos para la concesión de permisos o para el acceso al régimen de semilibertad, tal y como se observa en muchos pronunciamientos ${ }^{138}$.

Por todo ello, sería conveniente la eliminación del requisito legal (y su estricta interpretación jurisprudencial) relativo a la petición de perdón como prueba de la evolución en la resocialización que facilite o haga factible el progreso al tercer grado o determinados beneficios y enmarcarse en el tratamiento individualizado de cada interno, cuyo resultado deberá evaluarse conjuntamente para realizar una prognosis de reiteración delictiva.

b) La colaboración activa ${ }^{139}$ con las autoridades que puede plasmarse, a su vez en: impedir la producción de otros delitos por parte de la banda armada, organización o grupo terrorista; atenuar los efectos de su delito; identificar, capturar y procesar a los responsables de los delitos terroristas; obtener pruebas o impedir la actuación o desarrollo de la organización o asociación a las que hayan pertenecido o con las que hayan colaborado

Esta exigencia también resulta controvertida porque la capacidad para evitar conductas delictivas o detener a responsables no está al alcance de todos los miembros de la organización, pudiendo privilegiar a quienes ostentan posiciones de mayor responsabilidad dentro de la misma ${ }^{140}$ y porque no parece adecuado por inexigible forzar al condenado por un acto terrorista a asumir una situación de riesgo personal enfrentándose a la organización ${ }^{141}$. Hubiera sido preferible una redacción en términos más objetivos y

137 Así, GIL GIL, A., "El requisito de...” ob. cit., pág. 14.

138 Vid. el Auto del JVP de Barcelona de 1 de 27 de noviembre de 2007 en el que se alude al arrepentimiento para justificar un permiso de salida o el Auto del JVP de Salamanca de 8 de febrero de 2008, para la progresión al tercer grado,

139 Aduciendo la difícil compatibilidad de este requisito con el principio de legalidad por su falta de certeza e indeterminación, RIOS MARTÍN, J./ETXEBARRÍA, X./PASCUAL, E., Manual de ejecución penitenciaria. Defenderse en la cárcel, Madrid, 2018, pág. 29.

140 TAMARIT SUMALLA, J.M., La reforma penal..., ob. cit., pág. 107.

141 El requisito resulta, al tiempo, innecesario, por cuanto el art. 102.5 RP ya exige mantener el primer grado de tratamiento mientras no se muestren signos inequívocos de haberse sustraído a la disciplina interna de la 
similares a los descritos en el art. 579 bis $.3 \mathrm{CP}$ que permite rebajar la pena uno o dos grados en los delitos de terrorismo por el comportamiento postdelictivo consistente en el abandono voluntario de las actividades delictivas, ya que este comportamiento como la confesión de los hechos delictivos adquieren un mayor sentido como fundamento de una atenuación en la pena que como requisito de una figura penitenciaria que se funda básicamente en la evolución individual del interno en términos subjetivos.

\section{EL PERIODO DE SEGURIDAD EN LA PRISIÓN PERMANENTE REVISABLE}

La pena de prisión permanente revisable introducida por LO 1/2015 y recientemente declarada formalmente acorde con el Texto constitucional ${ }^{142}$, contiene unas previsiones específicas para la suspensión ${ }^{143}$ de su ejecución o, en los términos legales, para lo que significa su revisión (art. 36.1 en concordancia con el $92 \mathrm{CP}$ ).

Aun cuando la cuestión pueda presentar un escaso interés a nivel práctico inmediato atendiendo al escaso número de figuras delictivas que actualmente la llevan anudada como sanción y la excepcionalidad de la comisión de tales hechos delictivos de suma gravedad - abstracción hecha de los asesinatos cualificados introducidos ad hoc por la reforma $-{ }^{144}$ y al tiempo mínimo que habrá de transcurrir hasta que deba hacerse efectivo, lo que daría de largo para que acontecieran otra veintena de reformas que le pudieran afectar, lo cierto es que el art. 36.1 inciso segundo del CP establece la revisión de esta pena conforme a lo previsto en el art. $92 \mathrm{CP}$ en cuya sede se destacan unos requisitos ineludibles, ente los que destaca en segundo lugar, junto al principal referido al hecho de

organización. Así lo pone de relieve, TELLEZ AGUILERA, A. "La Ley de cumplimiento íntegro y efectivo de las penas: una nota de urgencia” La Ley, 14 de agosto de 2003, pág. 4.

142 La citada STC 169/2021 de 6 de octubre (La Ley 179757/2021).

143 Cabe recordar que el art. $3 \mathrm{CEDH}$ obliga a introducir la revisión de la condena de manera que sea realmente posible su remisión cuando se constate un comportamiento del reo favorable y se hayan producido progresos en el tratamiento rehabilitador. A este respecto, se puede concluir que, ciertamente, no existe una barrera internacional que impidiera la introducción de esta pena en nuestro ordenamiento, pero también que el TEDH ha basado siempre la adecuación de esta pena al precepto mencionado en que la posibilidad de revisión sea "real y efectiva" para que el penado tenga la ocasión de reinsertarse, garantizando que los mecanismos previstos propendan a la suspensión del resto de la pena y no la dificulten o conviertan en imposible. Por tanto, la contravención al Convenio vendría dada no solo cuando no esté prevista la posibilidad de revisión, sino también cuando los mecanismos sean difusos, dependientes de la voluntariedad del órgano decisor y no del comportamiento objetivo del sujeto. La configuración que se le otorga en nuestro ordenamiento y su carácter formalmente revisable, no la hace automáticamente aceptable por lo poco taxativo e indefinido del procedimiento. Vid., en estos términos, STDH sección 4a de 18 de septiembre de 2012, caso James, Wells and Lee v. The UK párrafos 165 y ss. y 210. (La Ley 140917/2012). Se señala, recordando el Pacto de Derechos Sociales y políticos de 1966, que el sistema penitenciario procurará un tratamiento dirigido a su reforma y rehabilitación social, que la persona privada de libertad tendrá un trato humanitario y con respeto a la dignidad. En consecuencia, se afirma que mantener a una persona privada de libertad por una razón de "protección púbica" es contrario al art. 5 de la Convención, constituyendo una "estructura seriamente defectuosa".

144 Asesinatos cualificados (Art. 140 CP); muerte del Rey o del príncipe heredero (art.485.1 CP), muertes en actos de terrorismo (art.572.2.1 entonces vigente, actual 573 bis. 1 CP); muerte del jefe de un Estado extranjero (art.605 $\mathrm{CP}$ ); genocidio (art. $607 \mathrm{CP}$ ) y crímenes de lesa humanidad (art.607 bis CP). Resulta dudosa, sin embargo, la aplicabilidad de esta pena a los supuestos de muertes terroristas, por cuanto, finalmente el citado precepto castiga tales atentados con la pena "de prisión por el tiempo máximo previsto en este Código", por tanto, con la pena de prisión temporal máxima que no es otra que 30 años y no la Prisión Permanente Revisable que es, atendiendo al propio tenor del art. 36.1CP, una pena distinta. Ello en un escrupuloso respeto al principio de legalidad. 
haber cumplido 25 años de condena, la necesidad de que el penado se encuentre clasificado en tercer grado Esto nos lleva a los periodos de seguridad (distintos dependiendo de la tipología delictiva) establecidos para la prisión permanente revisable.

Para desgranar este requisito es preciso tener en consideración por una parte, las restricciones previstas para el acceso al tercer grado consignadas en el propio art. $36.1 \mathrm{CP}$ que viene a definir la pena en función de su tratamiento penitenciario, así como las previstas en el art. 78 bis $\mathrm{CP}$, apartados 1 y 2 para las hipótesis de concurrencia delictiva. Por otro, también hay que tener en cuenta las previsiones establecidas en los apartados 5 y 6 del art. 72 LOGP ya analizadas y que resultan igualmente de aplicación al estar referidos a las penas privativas de libertad.

Una de las cuestiones relativas a la ejecución de la pena de prisión permanente revisable (art. 36.1 CP) es la relativa al acceso al tercer grado, en relación a la cual se ha establecido, como no podía ser de otro modo teniendo en cuenta el máximo de pena de prisión temporal previsto en el texto punitivo para una sola infracción (30 años), un doble periodo de seguridad especialmente riguroso, a tenor del cual el régimen de semilibertad no podrá alcanzarse hasta haber cumplido el penado quince años de prisión efectiva, esto es, de internamiento en régimen ordinario en Centro penitenciario, llegando a alcanzar este periodo blindado los veinte años en caso de haberse impuesto la pena por un delito de terrorismo (delito del Capítulo VII del Título XXII del Libro II de este Código).

Para centrar la relevancia del precepto debe partirse del entendimiento de que el denominado sistema de individualización científica que rige en nuestro sistema penitenciario y consagrado en el art. 72 LGP para potenciar la resocialización del delincuente, dejó de ser enteramente ajeno al cumplimiento de los plazos desde la entrada en vigor de la ley 7/2003 y restándole plasticidad al sistema, decidió impedir como regla general, la posible clasificación en tercer grado de tratamiento a los condenados por penas superiores a los cinco años de privación de libertad sin tener en cuenta las consecuencias negativas que ello podría comportar. Siendo esto así, el periodo de seguridad no podía dejar de estar presente en la configuración de la pena más gravosa de nuestro ordenamiento, no ya en cuanto a duración, sino en cuanto a la dureza de su ejecución, si bien con particularidades.

Así, la LO 1/2015, tras incorporar la pena de prisión permanente, vuelve a insistir en la fijación de plazos diferentes para la clasificación en tercer grado de tratamiento, imponiendo un periodo de seguridad obligatorio para los condenados a esta pena, variando el mismo según el delito cometido (art 36.1 CP). Con ello se impide que se tengan en consideración las circunstancias del hecho, o del autor (el pronóstico de integración social su personalidad o su conducta $)^{145}$, puesto que durante este periodo de tiempo -15 o 20 años, según el delito-, la individualización científica brillará por su ausencia, soportando injustamente Instituciones Penitenciarias estos cambios repentinos e injustificados en el Derecho penal sustantivo. Y es que un sistema que se pretende sea flexible y enfocado a los fines de resocialización, debe tener como criterio rector las circunstancias del interno para concretar un programa individual de tratamiento, su clasificación inicial en un determinado grado y, en consecuencia, su destino al tipo de establecimiento más adecuado a su clasificación. Esto, como es lógico, se contrapone

145 Arts. 65.2 y 3 LOGP, así como arts. 106.2 y 3 RP. 
al hecho de que el paso por cada grado sea obligado y se establezcan periodos mínimos de cumplimiento para la progresión en el tratamiento ${ }^{146}$. Sin embargo, al mismo tiempo, el art. 36.1 CP condiciona previamente la clasificación en tercer grado a un pronóstico individualizado y favorable de reinserción social, oídos el Ministerio Fiscal e Instituciones Penitenciarias.

Así pues, la posibilidad de acceder al tercer grado está sometida a un elemento objetivo (temporal) y otro valorativo previo, de modo que la amenaza de la pena se centra no ya en su límite, que es incierto, sino más bien en la dureza de su ejecución que se muestra enormemente inflexible. Respecto al elemento temporal, dejando al margen los supuestos de concurrencia criminal en función del tipo delictivo ${ }^{147}$ recogidos en el art. 78 bis $\mathrm{CP}^{148}$, el sistema que pudiera denominarse ordinario -se comete un único delito castigado con esta pena indeterminada- establece una distinción entre el tiempo que se requiere en caso de cometer cualquier delito a la que se le anude (15 años) y el necesario en caso de delitos de terrorismo (20 años) bajo el fundamento de la mayor gravedad de estos delitos que conduce a imponer un periodo de seguridad mayor ${ }^{149}$. Resulta destacable, no obstante, que esta regulación del periodo de seguridad para acceder al tercer grado se suaviza notablemente respecto al Borrador y el Anteproyecto de reforma de julio de 2012. De los 32 años previstos en aquel texto primitivo se pasó a fijar en el Anteproyecto presentado por el Gobierno el 11 de octubre de $2012^{150}$ los plazos actualmente vigentes (15 o 20). Su cuantía se corresponde, en puridad, con las penas más graves de nuestro ordenamiento, esto es, con unas penas individuales temporales de 30 y 40 años.

Establecer una mayor dilación en el tiempo necesario para poder alcanzar el tercer grado según la tipología delictiva, sigue la tónica general de distinguir en los institutos penitenciarios los delitos de terrorismo del resto de condenas otorgándole a los primeros un régimen más gravoso, pero supone, al tiempo, una ruptura frontal con el criterio acogido por el CP para la prisión temporal en el apartado siguiente, sede en la que la cuantía de pena efectivamente cumplida no se modifica en función de los distintos delitos, variando, únicamente el carácter preceptivo o no del periodo de seguridad. Si la progresión al tercer grado es la consecuencia de una evolución favorable en el tratamiento penitenciario

146 Frente a los planteamientos preventivo-especiales, encontramos voces que, mencionando las necesidades de prevención general, reclaman el cumplimiento obligatorio de un determinado periodo de tiempo de condena para poder acceder a los beneficios penitenciarios, aun cuando la evolución personal del penado fuera positiva. Así, NISTAL BURÓN, J. “¿Es viable en nuestro ordenamiento jurídico la pena de "cadena perpetua” como solución para determinado tipo de delincuentes difícilmente reinsertables?". La Ley penal, $n^{\circ}$ 68, Sección Estudios, febrero, 2010. (La Ley 119/2010), pág. 3.

147 Vid., estructurados en tablas el modelo ordinario y los extraordinarios de acceso al tercer grado, FUENTES OSORIO, J. F., "Periodos de cumplimiento mínimo para el disfrute de beneficios penitenciarios y permisos de salida”, en Comentarios a la Reforma penal de 2015, (QUINTERO OLIVARES, G., Dir.), ob. cit., págs. 128-132.

148 Casos en los que el sujeto fuere condenado por dos o más delitos, siendo uno de ellos castigado con prisión permanente o incluso cuando hayan recaído varias condenas de prisión permanente exigiéndose en tales casos un mínimo de 18, 20 o 22 años, ampliándose tales plazos a 24 o 32 si se tratase de condenas por delitos de terrorismo o cometidos en el seno de organizaciones criminales. Como puede observarse, la regulación de la prisión permanente revisable ha previsto la posibilidad de lograr el tercer grado, una vez cumplido un periodo de carácter obligatorio que oscila entre los 15 años y los 32 años-

149 En este sentido, el Dictamen del Consejo de Estado al Anteproyecto de Reforma, octava (B).

150 También a los veinte años de cumplimiento inicial "en todo caso" que proponía el Grupo Popular al intentar introducir esta pena en el Proyecto de Reforma de 2010 (Ley 121/52, 19 de noviembre de 2009). Vid. enmienda núm. 387. BOCG. Congreso de los Diputados, Serie A, Proyectos de ley, nº 52-9, 18 de marzo de 2010. 
y si las modalidades delictivas, se supone que de gravedad equiparable, son sancionadas con la misma pena, el establecimiento de un tiempo de prisión efectiva distinto ${ }^{151}$, más grave en algunos casos, denota el propósito de endurecer el régimen de cumplimiento atendiendo, exclusivamente, al tipo de delito cometido en lo que es un claro ejemplo de un Derecho penal de autor ${ }^{152}$.

La segunda exigencia ${ }^{153}$ para alcanzar el tercer grado, está referida al pronóstico individualizado y favorable de reinserción social ${ }^{154}$, oídos el Ministerio Fiscal e Instituciones Penitenciarias, siguiendo el criterio competencial establecido por el art. 36.2 CP para el periodo de seguridad de la pena de prisión, aunque ello supone apartarse de la regla general de concesión por el Centro Directivo previa propuesta de la Junta de Tratamiento (art. 103.4 RP). Esta autorización de acceso al tercer grado es similar al levantamiento del periodo de seguridad, con la importante diferencia de que en el caso de la prisión ordinaria o temporal lo concede el Juez de Vigilancia Penitenciaria iniciando el procedimiento la Junta de Tratamiento que lo propone a dicho órgano, valorando como criterios favorables la asunción del delito, la actitud de respeto a la víctima, la conducta en libertad después de la comisión del delito y la participación en programas de tratamiento, mientras que el caso de la prisión permanente revisable, esta atribución corresponde, sorprendentemente, al Tribunal sentenciador que será quien conceda o no el tercer grado.

En efecto, hay que recordar que el Anteproyecto de julio de 2012 establecía en un apartado tercero del art. $36 \mathrm{CP}$ que "en el caso de que hubiera sido impuesta una pena de prisión permanente revisable, la concesión de permisos de salida o la progresión a tercer grado requerirán de la existencia de un pronóstico individualizado y favorable de reinserción social adoptado por el Juez de Vigilancia Penitenciaria (...)” y que es el segundo Anteproyecto presentado en octubre de 2012 el que ya se refiere, como en la actualidad, al "tribunal" (sentenciador). Sin embargo, en coherencia con todo el sistema de ejecución de las penas privativas de libertad, hubiera sido preferible dejar su concesión en manos del Juez de Vigilancia por su mayor especialización y proximidad con el penado y sus circunstancias ${ }^{155}$. Esta modificación, seguramente no inocente, presenta un sentido mar-

151 Por el contrario, y puesto que esta situación no se ha contemplado expresamente en el art. $78 \mathrm{CP}$, habrá que entender que si son varios delitos, uno castigado con prisión permanente revisable y el resto suman penas inferiores a cinco años resultará aplicable la regla general contenida en el art. $36.1 \mathrm{CP}$, pudiendo el sujeto alcanzar el tercer grado a los 15 años de cumplimiento, aun cuando esto pudiera provocar un efecto criminógeno, al no ser tomadas en consideración estas otras penas menos graves, lo que analizado en término de costes, puede significar que al sujeto le resulta indiferente cometer algunos delitos de esta entidad acompañando al que lleva aparejada la pena de prisión permanente revisable, que no serán computables.

$152 \mathrm{El}$ mismo CGPJ en su Informe al Anteproyecto pone de manifiesto que el establecimiento de un requisito temporal de mayor duración para el acceso al tercer grado a causa de la especial tipología delictiva, supone "una quiebra de la sistemática seguida por el CP y no resulta conveniente ni jurídicamente fundado". Para LEGANÉS GÓMEZ, S., esto contribuye a la consideración de los delitos de terrorismo como delitos políticos y a aplicar un "Derecho penal del enemigo". "La prisión permanente revisable y "los beneficios penitenciarios"”, La ley penal, n 110, 2014, pág. 26.

153 Habrá que considerar que, además de los especificados en el art. $36.1 \mathrm{CP}$, deben contemplarse el resto de los requisitos contemplados en la LOGP, esto es, la capacidad de vivir en semilibertad y el pago de la responsabilidad civil (art. 72.5), así como los específicos previstos para condenados por delito de terrorismo (colaboración con las autoridades y petición expresa de perdón a las víctimas (art. 72.6).

154 Es difícil imaginar que estos penados puedan obtener un pronóstico favorable de reinserción social que le permita acceder al régimen abierto, especialmente si no se les ofrece un programa de tratamiento adecuado e individualizado.

155 Considerando, sin embargo, que no queda determinado quien puede establecer el acceso al tercer grado, si el tribunal de vigilancia o el sentenciador, debiendo determinarse en una norma procesal, CARBONEL MATEU, 
cadamente reaccionario dirigido a la supresión de funciones de los Jueces de Vigilancia Penitenciaria que vienen contribuyendo de forma decisiva a la protección de los derechos de los reclusos.

En cualquier caso, la atribución de la competencia para la clasificación en tercer grado del penado al tribunal sentenciador -si bien pueda recurrir su decisión ante el JVPprecisa una importante y urgente adecuación de la legislación penitenciaria que hubiera sido deseable se produjera de forma coordinada en la misma LO 1/2015, así como del sistema de recursos previsto en general contra la resoluciones del JVP, adecuándose a esta novedosa competencia atribuida a los tribunales sentenciadores, que, por lo demás, dada la extensión mínima de la pena y los imprecisos requisitos para la revisión serán órganos que habrán cambiado inevitablemente su composición.

Este extraño criterio competencial adoptado puede obedecer, buscando una explicación plausible, a la naturaleza misma de los delitos para los que se ha previsto esta pena, con la idea puesta en que no se pierda de vista la infracción cometida y su trascendencia social ${ }^{156} \mathrm{y}$, por tanto, con un razonamiento basado más en razones propias de un Derecho penal de autor que en las propias de prevención especial positiva que deberían fundamentar esta figura que pretende un acercamiento pausado a la libertad. Si el tercer grado se logra cumpliendo los requisitos mencionados (temporal y de autorización por el tribunal previo pronóstico individualizado y favorable de reinserción social) es predecible la disparidad de soluciones que se presentarán en la práctica e incluso el alto grado de estigmatización de determinado tipo de presos condenados por la categoría a los que se les anuda esta pena. Este sometimiento a valoraciones personales abunda en la inseguridad jurídica que proporciona una pena que no es finita en su límite superior y cuya revisión se presenta de forma etérea.

En otro orden de cosas, es de reseñar cómo el propio texto establece una discriminación entre las víctimas de los delitos castigados con esta pena respecto a aquellas otras que lo son a consecuencia de delitos castigados con pena de prisión temporal. Así, cuando se trata de una pena de prisión superior a cinco años, tal y como se ha analizado, la clasificación penitenciaria (la vuelta al régimen general de cumplimiento) será adoptada por el JVP "previo pronóstico individualizado y favorable de reinserción social y valorando, en su caso, las circunstancias personales del reo y la evolución del tratamiento reeducador, oídos el MF, Instituciones penitenciarias y las demás partes", sin embargo, a tenor del art. 36.1 CP, cuando se trata de la prisión permanente revisable las partes, esto es, la acusación particular y la popular, no participan en el proceso consultivo y quedan al margen del recorrido penitenciario del sentenciado, ya que el tribunal solo debe oír para adoptar su decisión sobre la progresión a tercer grado al Ministerio Fiscal e Instituciones Penitenciarias. Con esta apreciación no es que se pretenda dar más protagonismo a las víctimas en el devenir de la ejecución de la pena privativa de libertad en general, ni de esta en concreto por las razones ya expuestas, pero sí poner de relieve que sería deseable un trato igualitario, en uno $\mathrm{u}$ otro sentido.

J.C., "Prisión permanente revisable I (arts. 33 y 35)", en Comentarios a la Reforma de CP de 2015, GONZÁLEZ CUSSAC, J.L., (Dir.), Valencia, 2015, pág. 218.

156 En este convencimiento, GARRIDO LORENZO, M.A., "La libertad condicional tras la reforma por ley Orgánica 1/2015 de 30 de marzo. Revista del Ministerio Fiscal, No 0, 2015, pág. 62. 
Las partes, curiosamente, vuelven a aparecer en el apartado tercero a la hora de conceder el régimen de semilibertad por motivos humanitarios, a pesar de que en el Anteproyecto solo se había incluido al Ministerio Fiscal. Queda por saber si esta disparidad de tratamiento es intencionada, en cuyo caso habría que reconocer que, a pesar de la presión de determinados grupos de víctimas sobre el Gobierno para incluir esta pena de prisión permanente revisable, la influencia no ha llegado al punto de concederles una función determinante en la fase de ejecución de la pena por los peligros que ello puede conllevar, o si bien es producto, lo que es más probable, de un error de técnica legislativa, dada la premura y la falta de debate con la que fue aprobado el Texto de reforma que incorporara esta novedosa pena en el año 2015.

\section{BIBLIOGRAFÍA}

DíEz RIPOLLÉs, J.L. "La evolución del sistema de penas en España: 1975-2003”. RECPC, 2006.

Álvarez García, J. Consideraciones sobre los fines de la pena en el ordenamiento constitucional español. Granada, 2001.

Manzanares Samaniego, J.L. "El cumplimiento íntegro de la penas", Actualidad penal, no 1, 2003.

Arribas López, E. "Reflexiones en torno a los fines de la pena y a los regímenes de cumplimiento de la pena de prisión”. Revista Poder Judicial, núm. 77, 2005.

García Albero, R. y Tamarit Sumalla, J. M. La Reforma de la ejecución penal, Valencia, 2004.

FuENTES OsORIO; J.L. "Sistema de clasificación penitenciaria y el «periodo de seguridad» del art. 36.2 CP", InDret, $2011, \mathrm{n}^{\circ} 1$. 